
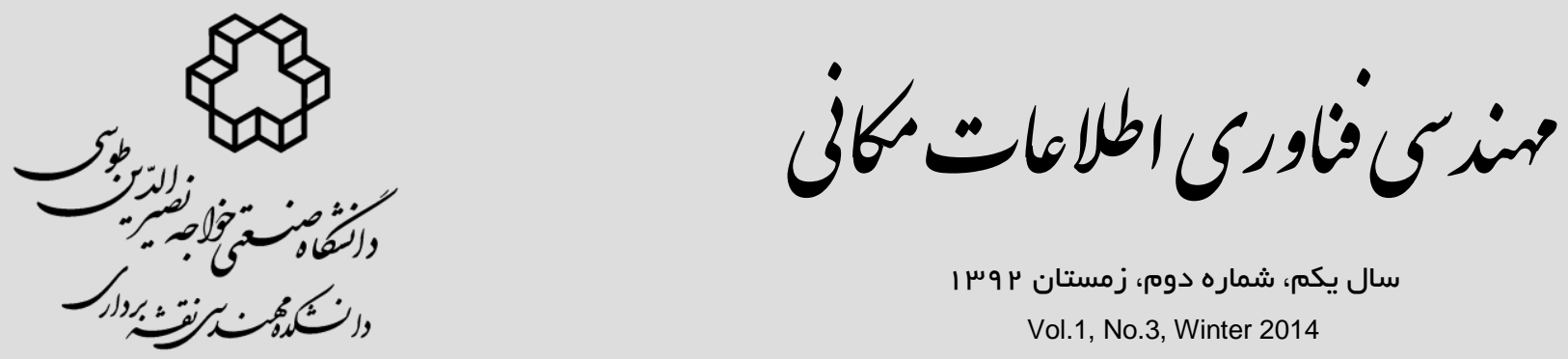

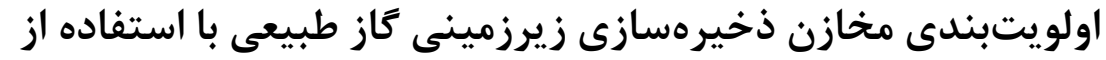

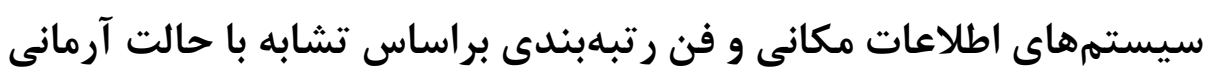

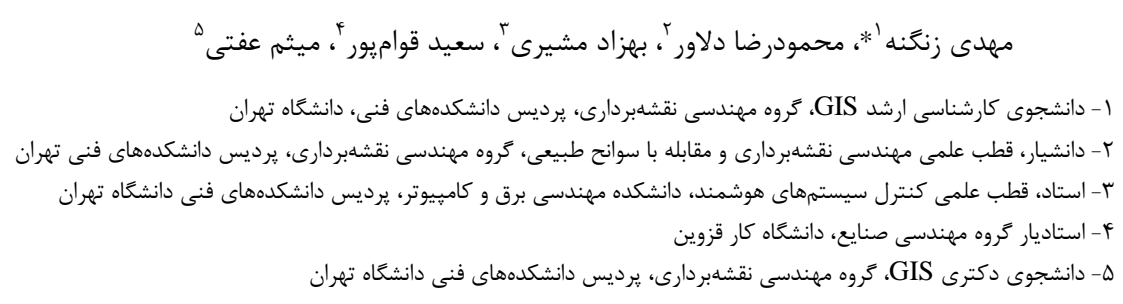

تاريخ دريافت مقاله: |

در اين تحقيق روشى مناسب و منطبق بر اصول علمى براى اولويتبندى ذخيـرهسازى كَاز طبيعى در مخـازن زيرزمينسى موجـود ارائهـ

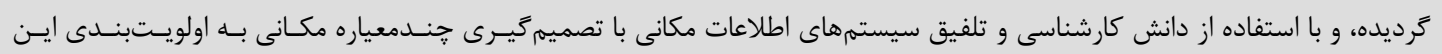

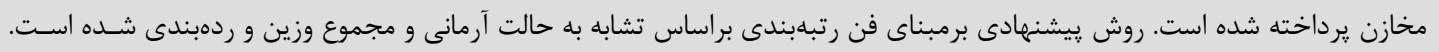

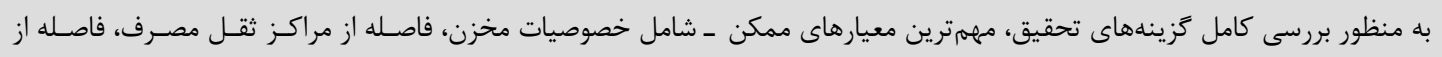

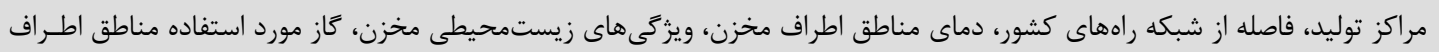

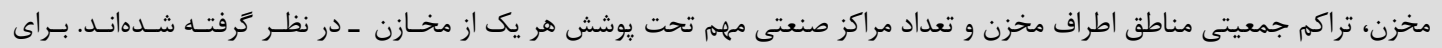

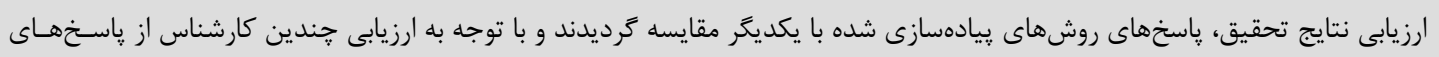

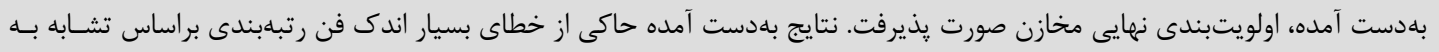

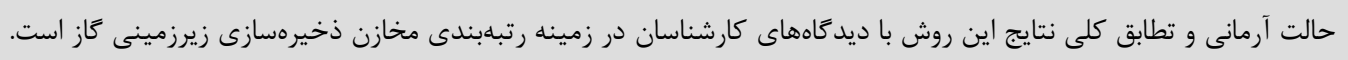
كليدوازمها: سيستمهاى اطلاعات مكانى، تصميم كيرى هندمعياره مكانى، ذخيرهسازى زيرزمينى كاز طبيعى، روش مجموع وزين و و ردمبندى شده، فن رتبلبندى براساس تشابه به حالت آرمانى.

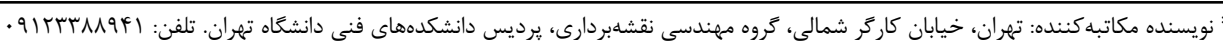


بالاترى هستند مشخص شود و سرمايه گذارى صـرفاً در

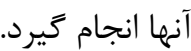

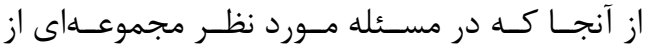

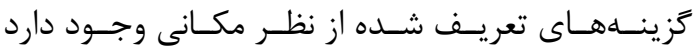
(مخازن) كه اين ززينهها براساس تعدادى شاخص مورد

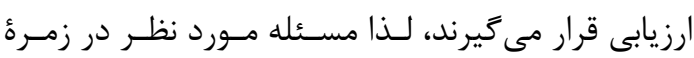

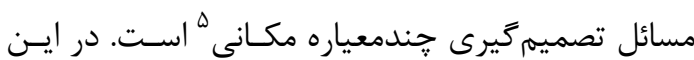
مسائل به قابليتهاى سيستمهــاى اطلاعـات مكـانى در زمينـ دريافت، ذخيرهسازى، بازيابى و يـردازش دادههــا

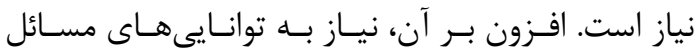
تصميمَّيرى جندمعياره نيز براى كنـار هـم قـرار دادن

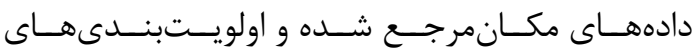

تصميهم گيرنده، به جشم مى خورد [1]].

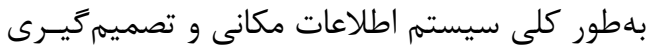

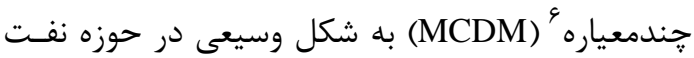

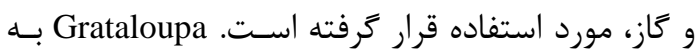
مكانيابى براى ذخيرهسازى زيرزمينى دى اكسيد كـربن

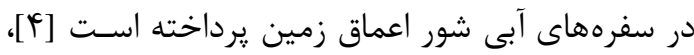
وى برمبناى برخى از معيارهاى خطرناى (منــاطقى كـهـ روى گسل قرار دارند، مناطق حفاظتشده و و جز اينهـا)،

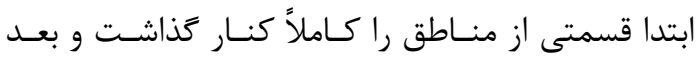
برمبناى معيارهاى احراز صلاحيت (فاصله تا مركز توليد

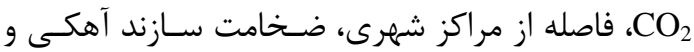

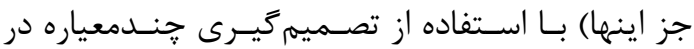

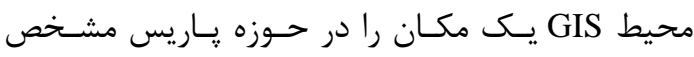
ساخت. Yami

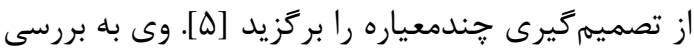
نحوه مجوز دادنِ شركت Aramco براى بهــرهبـردارى از

1. Depleted Reservoirs Storage

2. Aquifer Storge

3. Salt Cavern Storage

4. Geospatial Information System

5. Spatial Multi Criteria Decision Making

6. Multi Criteria Decision Making

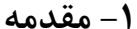

با توجــه بـهـ گَسـترش فزاينـده اسـتفاده كمّـى و تنـوع مصرف كاز طبيعى به عنوان يكـى از حـاملان فــراوان و ارزان انرزى و همجنين نامتعادل بودن عرضه و تقاضاى عاز طبيعى در فصـول سـرد، برنامـهـريـزى بـراى ايجـاد

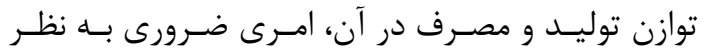

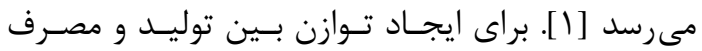
مى توان توان توليد كاز طبيعسى را بـالا بـرد، كـه البتـهـ

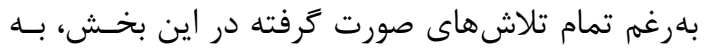
نظر مىرسد كه اين تلاشهـا بـراى تـأمين منـابع گَـاز كافى نيستند. البته ناخفته نماند كه از جمله راهكارهاى عملى در اين زمينه نيز ذخيرهسازى مازاد بر مصرف كاز

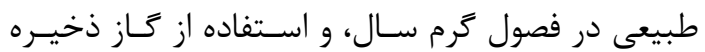
شده در فصول سرد سال است.

بهاطور كلى روش هاى متفاوتى بـراى ذخيـرهسـازى

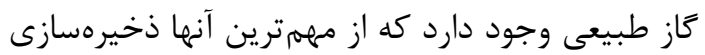
زيرزمينى است [1، r]]. براى اين كار، بهطور معمـول از

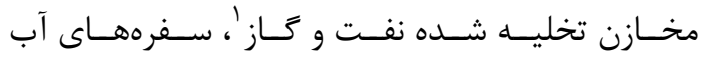

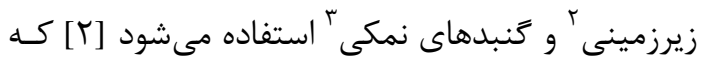

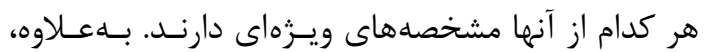
كفتنـى است با توجه به اينكـه سـالانه تعـدادى مخـزن زيرزمينى كَاز در كشـور شناسـايى مسىشـود و امكـان سرمايه كذارى در تمام اين مخازن وجود ندارد، بنـابراين ايجاد سيستمى كه از طريق آن بتـوان كـارايى مخــازن مختلف را با يكديخر مقايسه كرد، ضرورى مىنمايد. بدين ترتيب هدف كلى اين تحقيق در واقـع ايجـاد

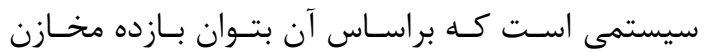
مختلف را با هم مقايسه كرد. مى توان كَفت بعد از اينكه جند مخزن به لحاظ زمينشناختى و مسائل فنى مــورد

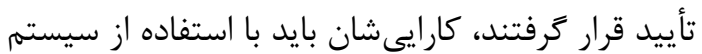

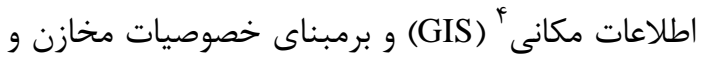
مهممترين معيارهاى ممكن مورد ارزيابى قـرار گيـرد. در

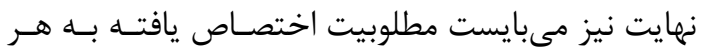
يك از مخازن بررسى گَردد، و رتبـهبنـدى ميـان آنهـا

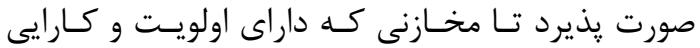


دوتايى، وزندهى را انجام دادند و براى تركيب وزنهاى

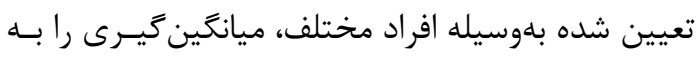

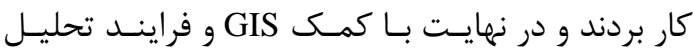

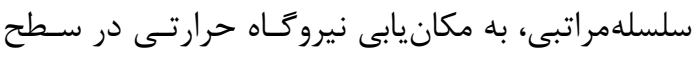

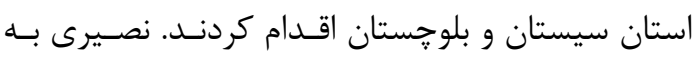

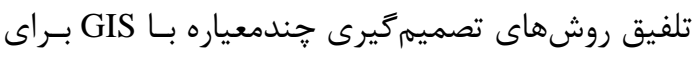

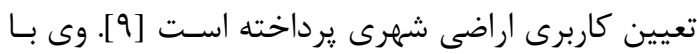

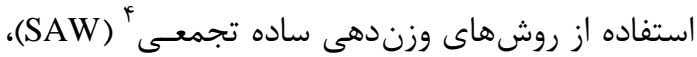

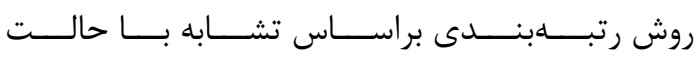

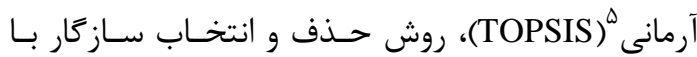

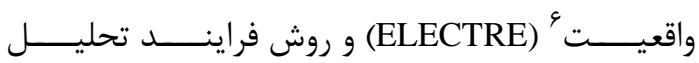

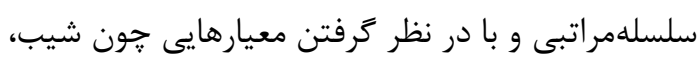

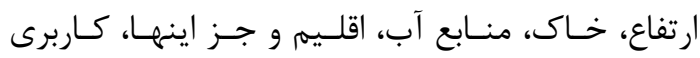
اراضسى شهرى را مشـخص سـاخت. بصـيرى و شـكور

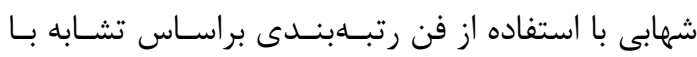

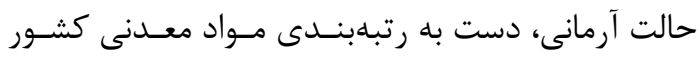

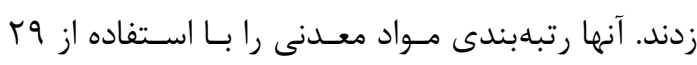

معيار انجام دادند [• [1].

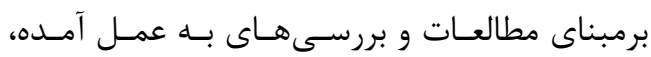

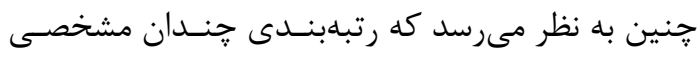

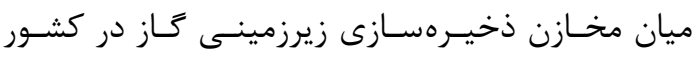

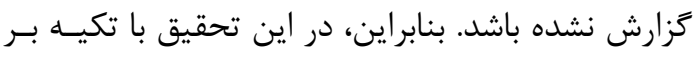

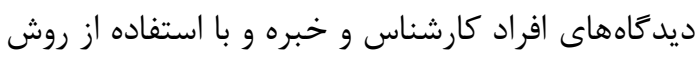

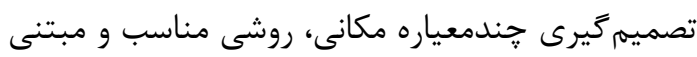

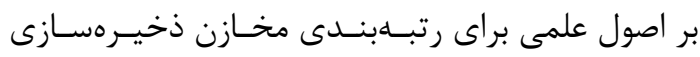

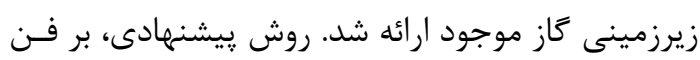

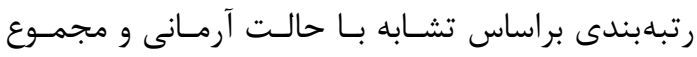

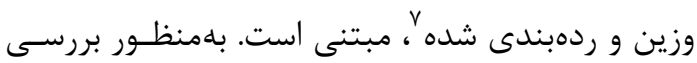

1. Sakhalin Energy

2. Liquid Natural Gas

3. Analytical Hierarchical Process

4. Simple Additive Weighting Method

5. Technique for Order Preference by Similarity to Ideal Solution

6. Elimination et Choice Translating Reality

7. Hierarchiecal Additive Weighting-Method
جاههاى نفت و كاز در عربستان يرداخت و با استفاده از

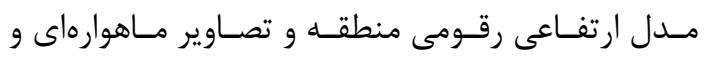

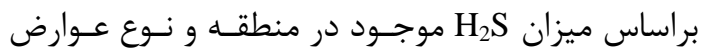

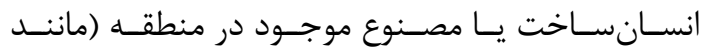
بيمارستان، هتل، ساختمان، جاده و نظـاير اينهـا)، جــاه

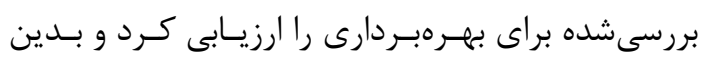

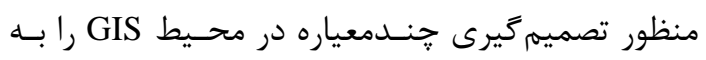

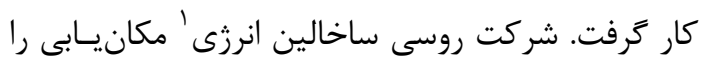

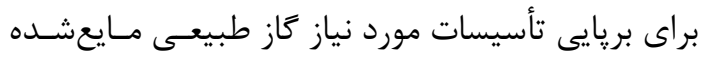

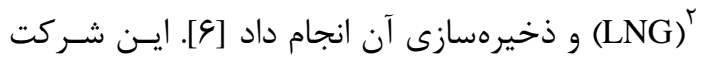

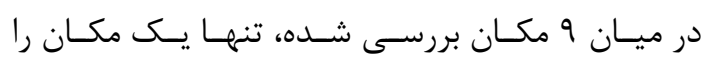

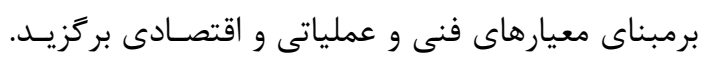

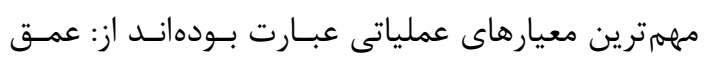

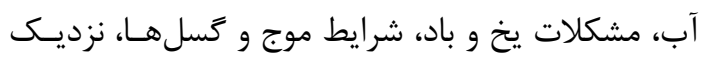

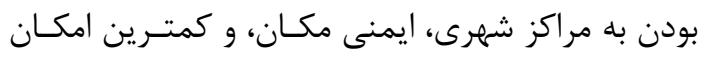
وقوع حادثه و اختلال در وضعيت ساكنان و مانند اينهـا.

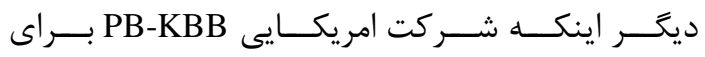

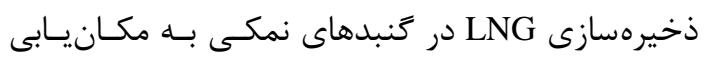

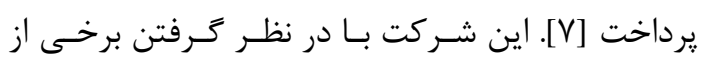

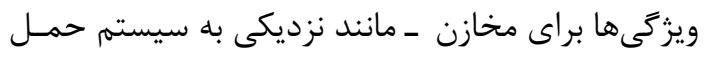

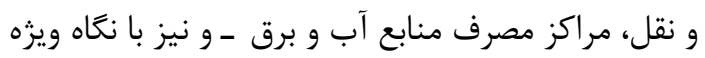

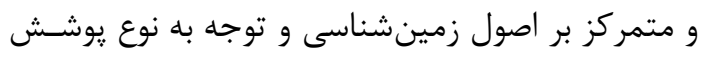

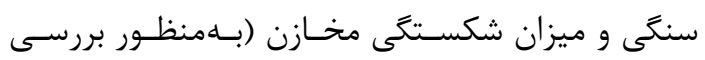

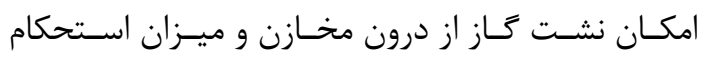

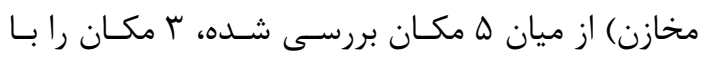
ايجاد تابع هزينه انتخاب كرد.

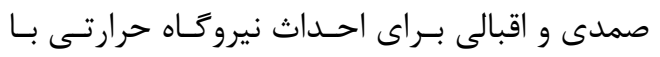

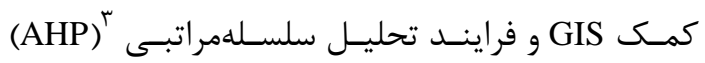

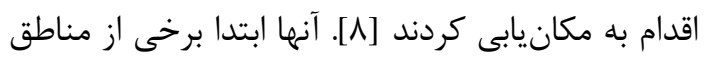

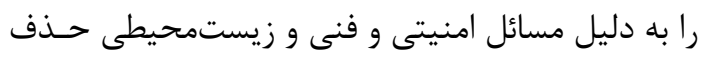

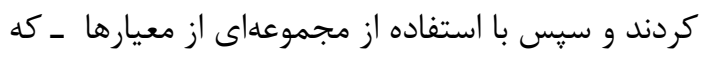

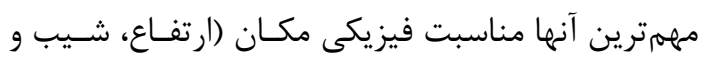

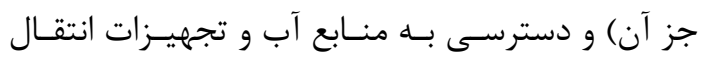

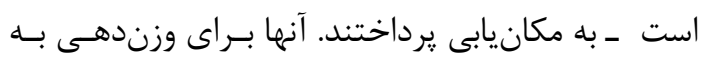
معيارها از نظر الم كارشناس استفاده كردند و با مقايسه 


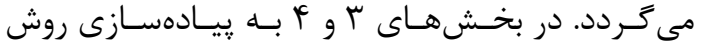

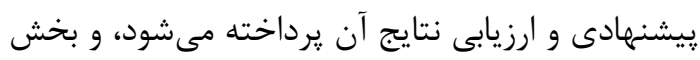
ه نيز به نتيجهَيرى اختصاص دارد.

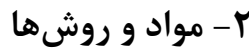

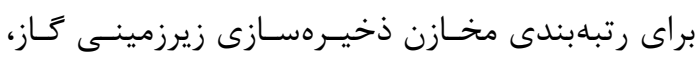
به كارگيرى فنون حل مسائل تصميمخيرى خنــدمعياره،

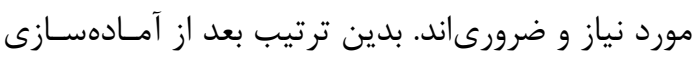

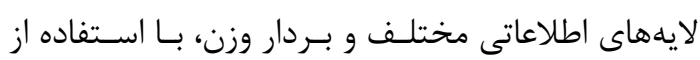

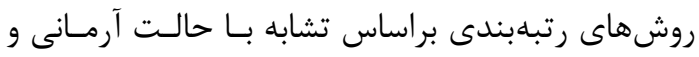

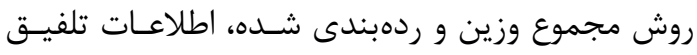
شدند و سرانجام رتبهبندى بين مخازن مختلف صـورئ ردورت

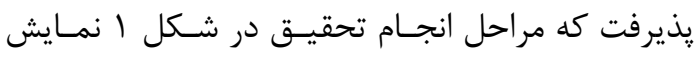
ماده شده است.
كامل زَينهاى تحقيق، مههمترين معيارهاى ممكن مــدّ

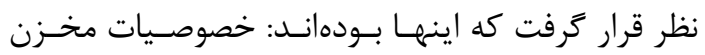

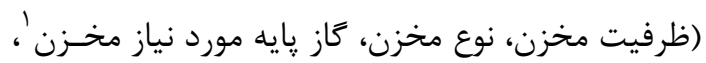

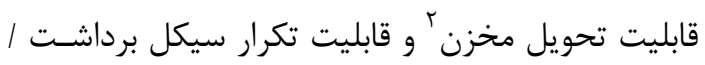
تزريق) و فاصله از مراكز ثقل مصـرف، فاصـله از مراكـز

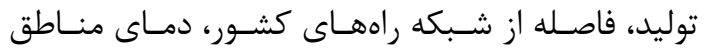
اطراف مخزن، ويزگىى هاى زيسـتمحيطى مخـزن، كَاز

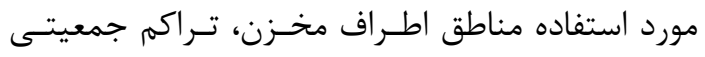

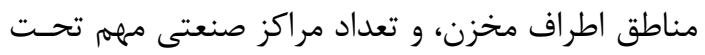
يوشش هر يك از مخازن. در نهايت براى ارزيسابى نتـايج

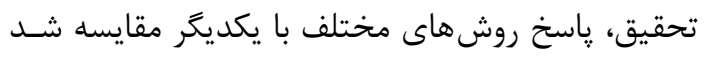

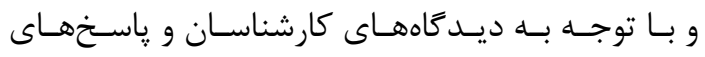
بهدست آمده، رتبهبندى ميان مخـازن مختلـف صـورت

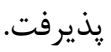
در ادامه، در بخش r ك، جزئيات روش يِيشنهادى ارائه

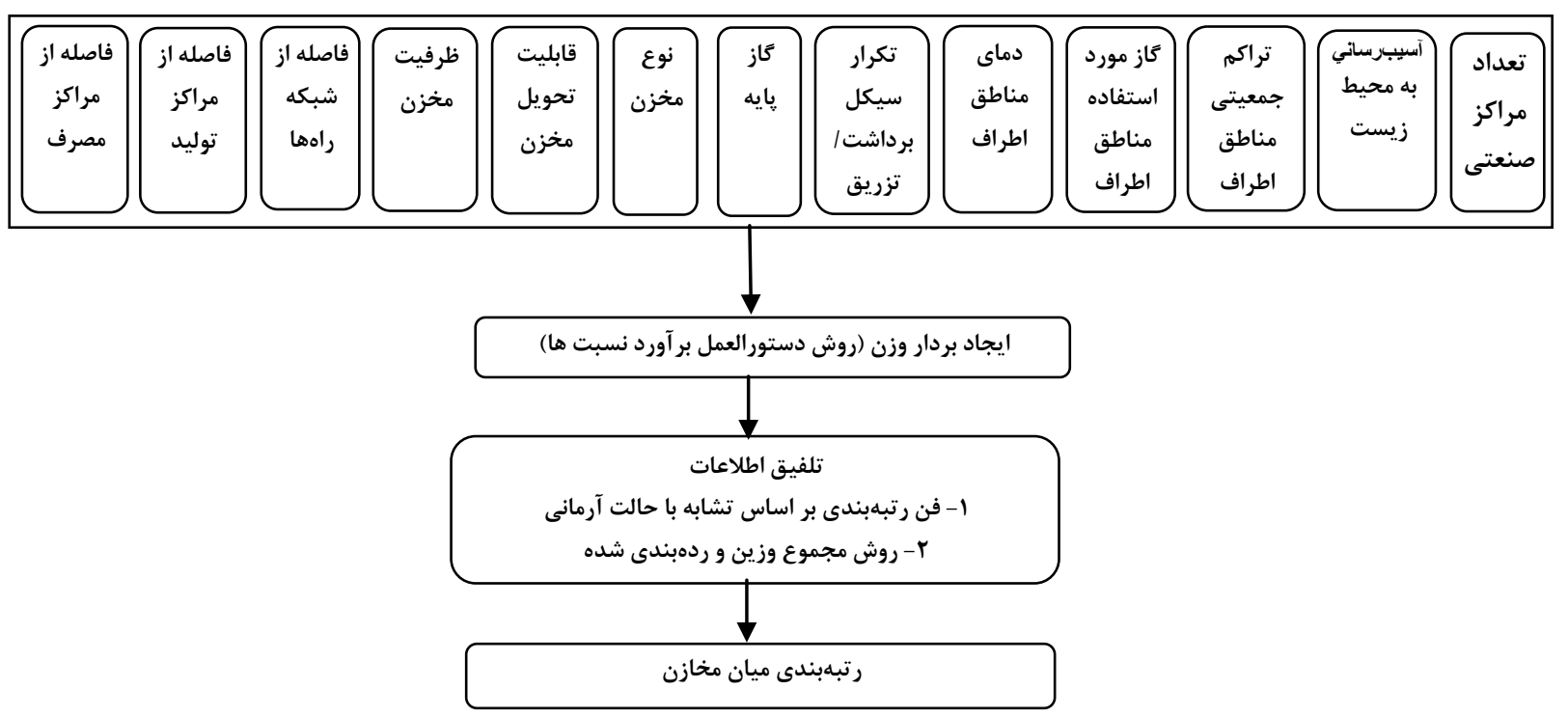

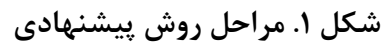

1. Base Gas

2. Deliverability 
خود دربردارندة m كَزينه و n معيار است. ايسن مـاتريس

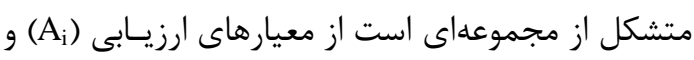

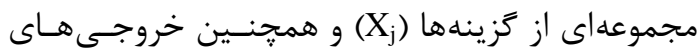

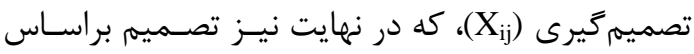

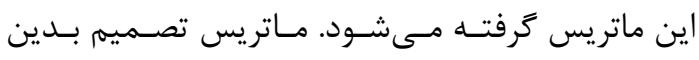
صورت فرموله مى گردد.

$\mathrm{X}_{1}$
$\mathrm{D}=\mathrm{A}_{1}$
$\vdots$
$\mathrm{A}_{\mathrm{i}}$
$\vdots$
$\mathrm{A}_{\mathrm{m}}$$\left[\begin{array}{ccccc}\mathrm{X}_{11} & \cdots & \mathrm{X}_{\mathrm{j}} & \cdots & \mathrm{X}_{\mathrm{n}} \\ \vdots & \vdots & \vdots & \vdots & \mathrm{X}_{1 \mathrm{n}} \\ \mathrm{X}_{\mathrm{i} 1} & \cdots & \mathrm{X}_{\mathrm{ij}} & \cdots & \mathrm{X}_{\mathrm{in}} \\ \vdots & \vdots & \vdots & \vdots & \vdots \\ \mathrm{X}_{\mathrm{m} 1} & \cdots & \mathrm{X}_{\mathrm{mj}} & \cdots & \mathrm{X}_{\mathrm{mn}}\end{array}\right]$

بهطور كلـى ايسن روش مشـتمل بـر و عرحلـه، بــهـ شرحى است كه در يى مى آيند:

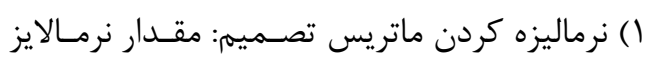

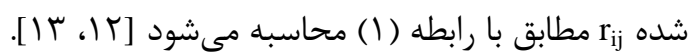

$$
r_{i j}=\frac{X_{i j}}{\sqrt{\sum_{i=1}^{m} X_{i j}^{2}}}
$$

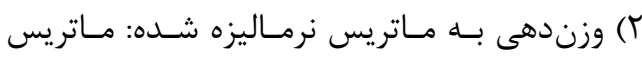

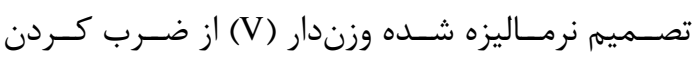

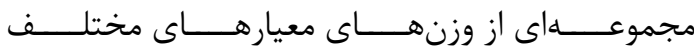
مات بس ماتريس تصميم نرماليزه شده بهدست مى آيد. نمونسهاى

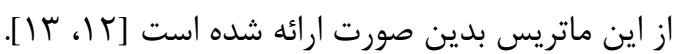

$$
\begin{aligned}
\mathrm{V}= & {\left[\begin{array}{ccccc}
\mathrm{W}_{1} \mathrm{r}_{11} & \cdots & \mathrm{W}_{\mathrm{j}} \mathrm{r}_{1 \mathrm{j}} & \cdots & \mathrm{W}_{\mathrm{n}} \mathrm{r}_{1 \mathrm{n}} \\
\vdots & \vdots & \vdots & \vdots & \vdots \\
\mathrm{W}_{1} \mathrm{r}_{11} & \cdots & \mathrm{W}_{\mathrm{j}} \mathrm{r}_{\mathrm{ij}} & \cdots & \mathrm{W}_{\mathrm{n}} \mathrm{r}_{\mathrm{in}} \\
\vdots & \vdots & \vdots & \vdots & \vdots \\
\mathrm{W}_{1} \mathrm{r}_{\mathrm{m} 1} & \cdots & \mathrm{W}_{\mathrm{j}} \mathrm{r}_{\mathrm{mj}} & \cdots & \mathrm{W}_{\mathrm{n}} \mathrm{r}_{\mathrm{mn}}
\end{array}\right]=} \\
& {\left[\begin{array}{ccccc}
\mathrm{V}_{11} & \cdots & \mathrm{V}_{1 \mathrm{j}} & \cdots & \mathrm{V}_{\mathrm{1n}} \\
\vdots & \vdots & \vdots & \vdots & \vdots \\
\mathrm{V}_{\mathrm{i} 1} & \cdots & \mathrm{V}_{\mathrm{ij}} & \cdots & \mathrm{V}_{\mathrm{in}} \\
\vdots & \vdots & \vdots & \vdots & \vdots \\
\mathrm{V}_{\mathrm{m} 1} & \cdots & \mathrm{V}_{\mathrm{mj}} & \cdots & \mathrm{V}_{\mathrm{mn}}
\end{array}\right] }
\end{aligned}
$$

همان طــور كـهـ اشـاره شـد، روشهــاى رتبــبنـــى

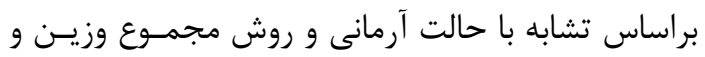

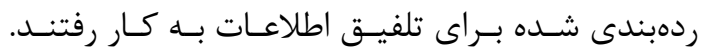

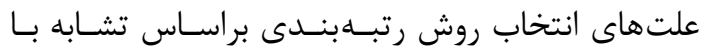

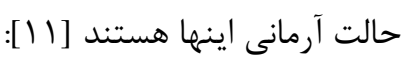

$$
\text { وجود استدلالى معتبر؛ }
$$

محاسـبه ارزش عـددى بــراى بهتــرين و بـدترين كزينها؛ دارا بودن فرايند محاسباتى ساده؛ و و عمدئ

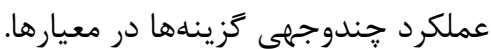

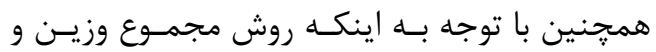
ردهبندى شده، روش كاربردى است كه كَزينـههـا را بـا

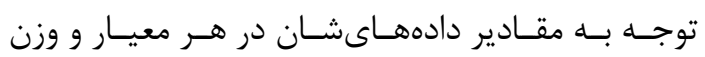
معيارها مورد مقايسه قرار مى دهد و همجنـين معيارهـا

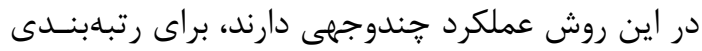

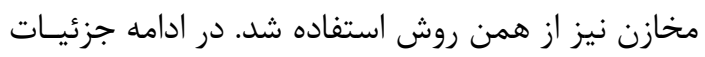

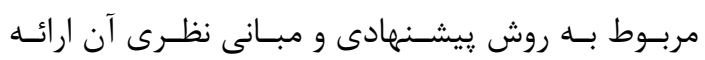

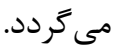

r-1- روش رتبهبندى براساس تشــابه بــا حالـــ آرمانى اين روش را نخستين بار هوانت و يـون در سـال 1911

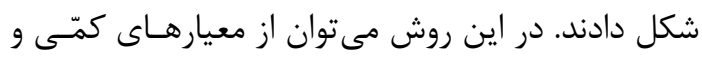

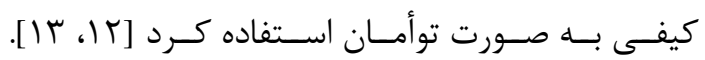
معيارهايى كه در اين روش به كار مىروند، به دو دسـته معيارهاى سود (داراى مطلوبيت يكنواخـت افزايشىى) و

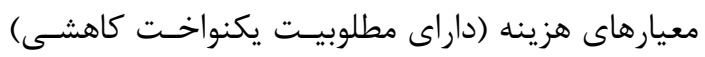

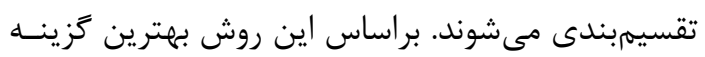

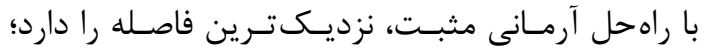

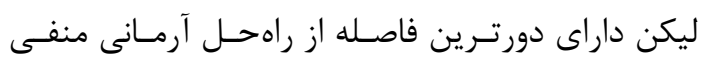

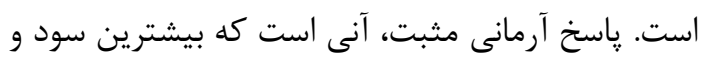
كمترين هزينه را در يـى داشــه باشـد؛ و وياسـخ آرمـانى

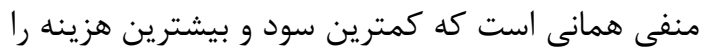

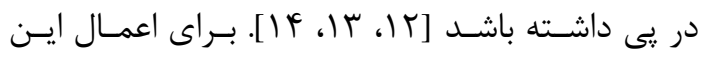
روش ابتدا بايد ماتريس تصميم (D) را ايجاد كـرد، كـهـ 


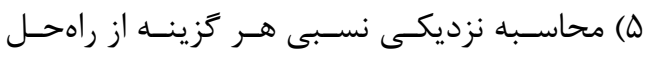

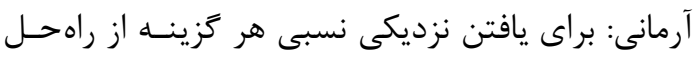

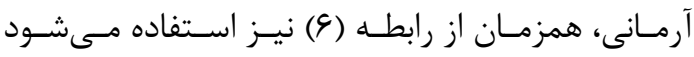

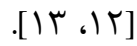

(9) (9)

$\mathrm{C}_{\mathrm{i}}^{*}=\frac{\mathrm{S}_{\mathrm{i}}^{-}}{\mathrm{S}_{\mathrm{i}}^{-}+\mathrm{S}_{\mathrm{i}}^{*}}$

كه در آن آن نشاندهنده نزديكى نسبى هر كزينـهـ

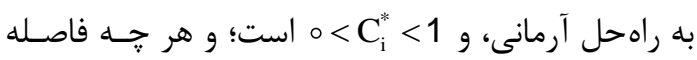

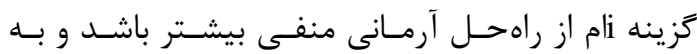

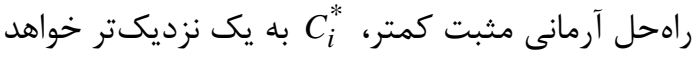
بود. ع) رتبهبندى كزينه ها: در اين مرحله كزينهها بـر

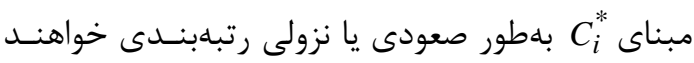

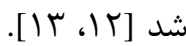

r-Y- روش مجموع وزين و ردهبندى شده

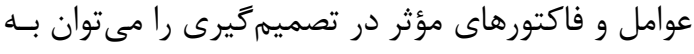

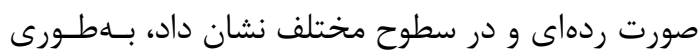

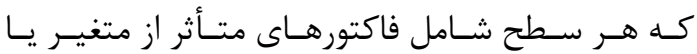

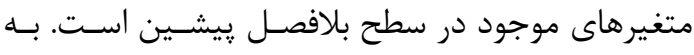

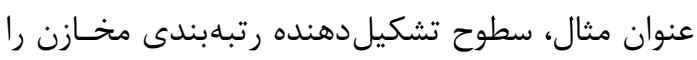
مى توان در شكل r مشاهده كرد. r) تعيين راهحل آرمانى مثبـت و منفـى: دو كزينـهـ

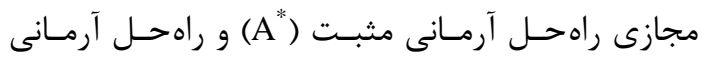

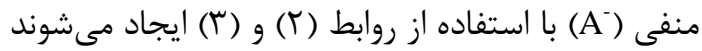

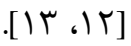

رابطه (r)
رابطه (ז)

$A^{-}=\left\{\left(\min _{i} V_{i j} \mid j \in J\right),\left(\max _{i} V_{i j} \mid j \in J^{\prime}\right)\right.$

$\mid \mathrm{i}=1,2 \ldots, \mathrm{m}\}=\left\{\mathrm{V}_{1}^{-}, \ldots, \mathrm{V}_{\mathrm{j}}^{-}, \ldots, \mathrm{V}_{\mathrm{n}}^{-}\right\}$

f) محاسـبه فاصـله: فاصـله هـر تزينـه لبُعـدى را

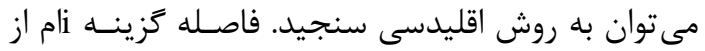

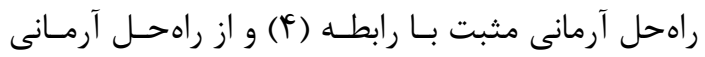

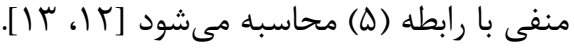

$$
\begin{aligned}
& S_{i}^{*}=\sqrt{\sum_{j=1}^{n}\left(V_{i j}-V_{j}^{*}\right)^{2}} \\
& \text { رابطه (a) }
\end{aligned}
$$$$
\text { رابطه (f) }
$$$$
S_{i}^{-}=\sqrt{\sum_{j=1}^{n}\left(V_{i j}-V_{j}^{-}\right)^{2}}
$$

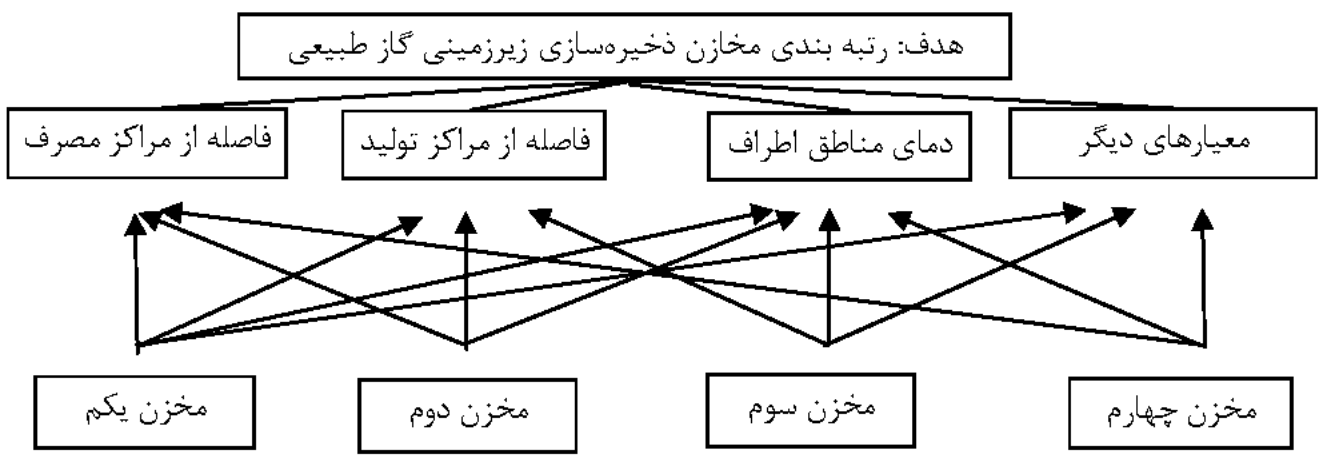

شكل r. سطوح فرايند رتبدبندى مخازن زيرزمينى كاز 


\section{r-r- إن- وزندهى به معيارها}

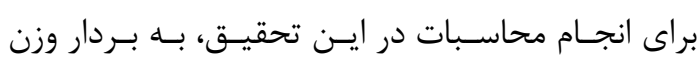

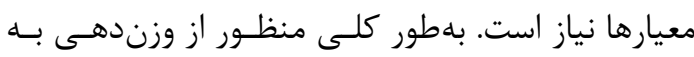

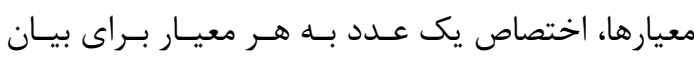

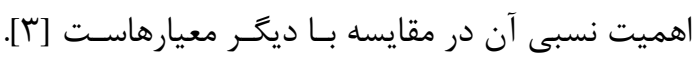

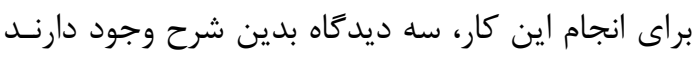

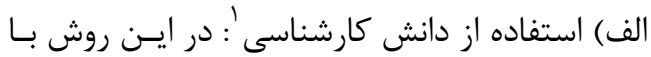

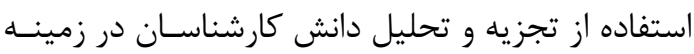

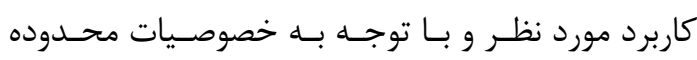

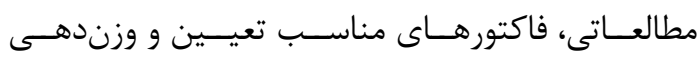

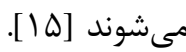

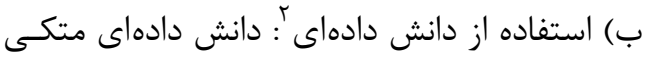

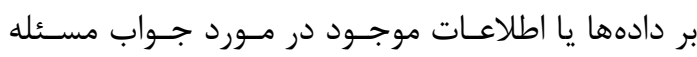

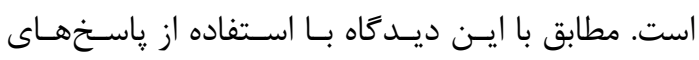

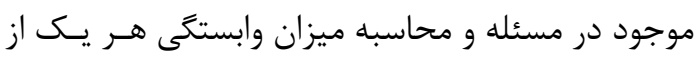

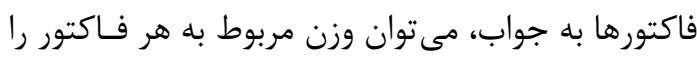

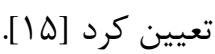

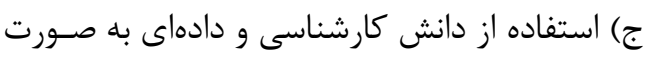

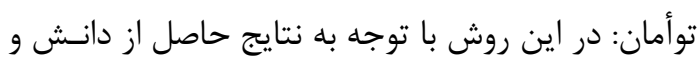

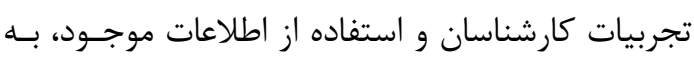

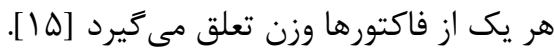

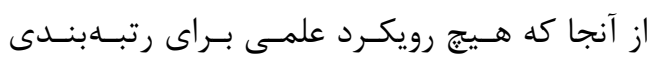

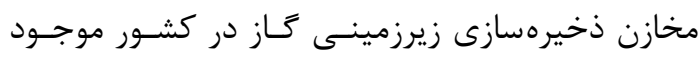

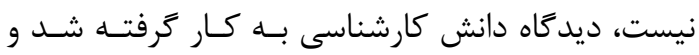

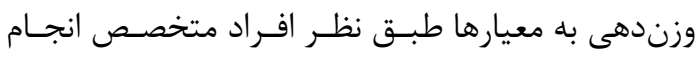

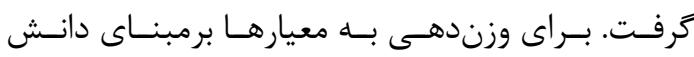

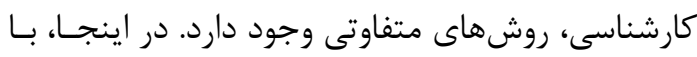

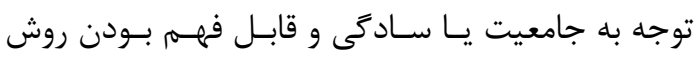

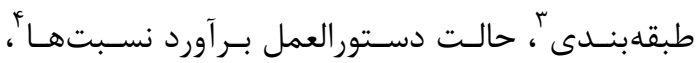

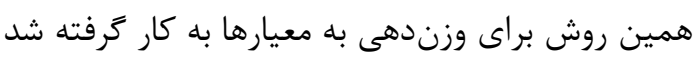

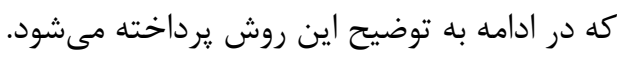

1. Knowledge Driven

2. Data Driven

3. Rating Method

4. Ratio Estimation Procedure

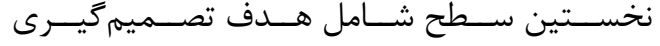

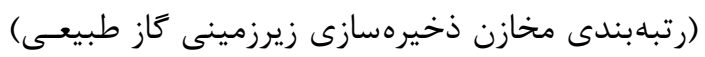

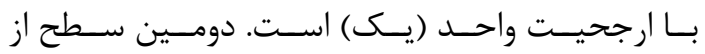

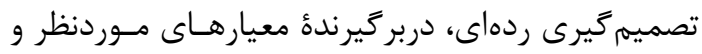

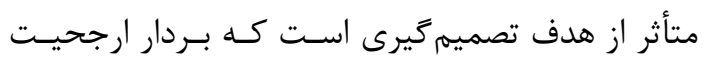

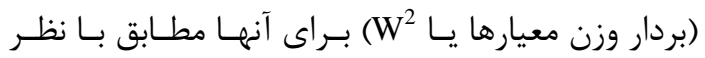

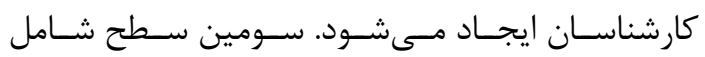

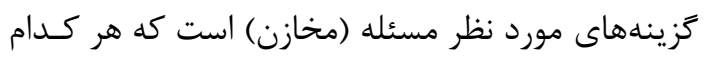

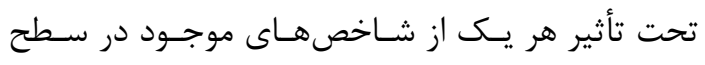

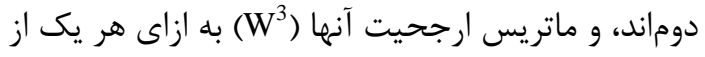
شاخصهاى موجـود در سـطح دوم نيـز بايـــ محاســبه

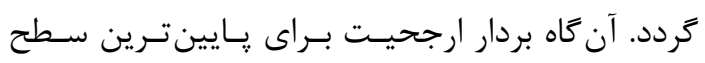

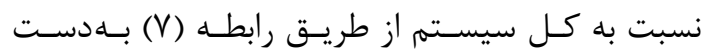
مى آيد [1 [1 ].
$\mathrm{W}_{\mathrm{B}=} \mathrm{W}^{3} * \mathrm{~W}^{2} * 1$
(V) رابطه

در اين روش معيارها به دو دسته معيارهاى سـود و

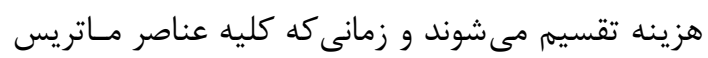

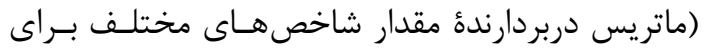

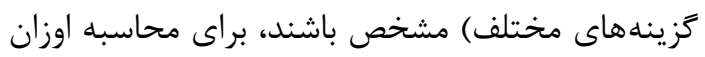

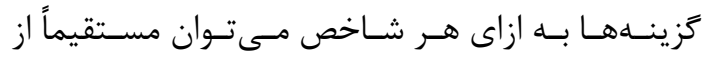

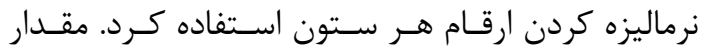

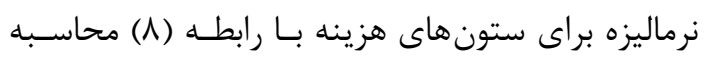

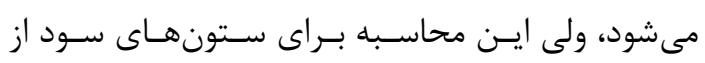

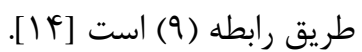
$\mathrm{C}_{\mathrm{j}}=\frac{\frac{1}{\mathrm{r}_{\mathrm{ij}}}}{\sum_{\mathrm{i}=1}^{\mathrm{m}} \frac{1}{\mathrm{r}_{\mathrm{ij}}}} \quad \mathrm{j}=1, \ldots, \mathrm{g} \quad($ ) $\mathrm{C}_{\mathrm{j}}=\frac{\mathrm{r}_{\mathrm{ij}}}{\sum_{\mathrm{i}=1}^{\mathrm{m}} \mathrm{r}_{\mathrm{ij}}} \quad \mathrm{j}=\mathrm{g}+1, \ldots, \mathrm{n} \quad$ (9) در ايــن روابـط، m تعـداد ززينــهـاسـت، n تعـداد

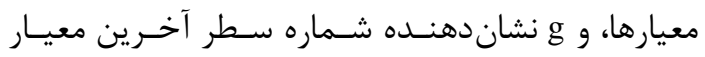

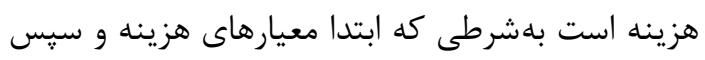

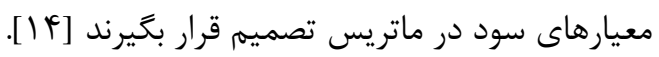


مخازن تهيه شد و سيس مطـابق بـا نظــــ كارشناسـان،

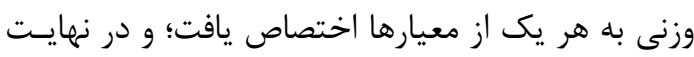

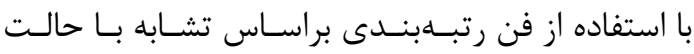

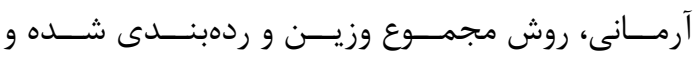

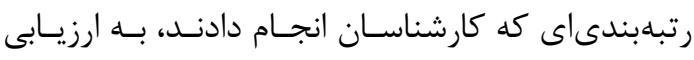
كزينههاى تحقيق يرداخته شد.

ب-1- تزينه هاى تحقيق (مخازن)

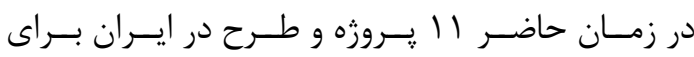

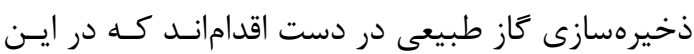

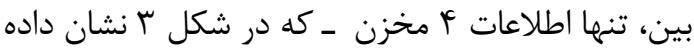
شدهاند ـ موجود و در دسترساند.

$$
\text { r-r-1 - دستور العمل بر آورد نسبتها }
$$

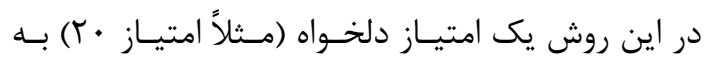

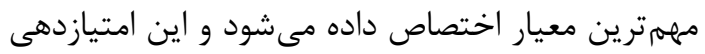
به همين ترتيب براى معيارهاى كماهميت تر نيـز انجـام مى كَيرد، تا برسد به كماهميت ترين برين معيار. سيس امتيساز

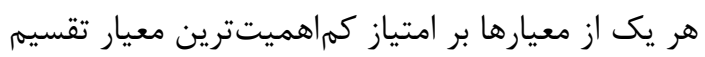

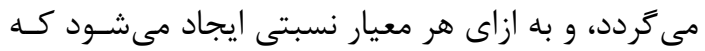

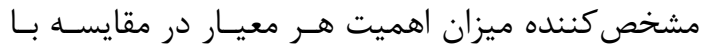

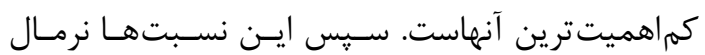

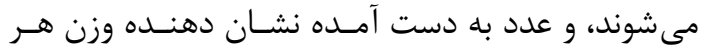
معيار، و مجموع وزنها برابر با يك است [بّ].

r- بيادهسازى تحقيق

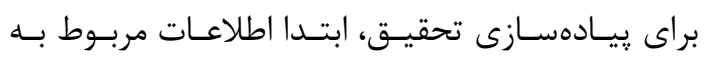

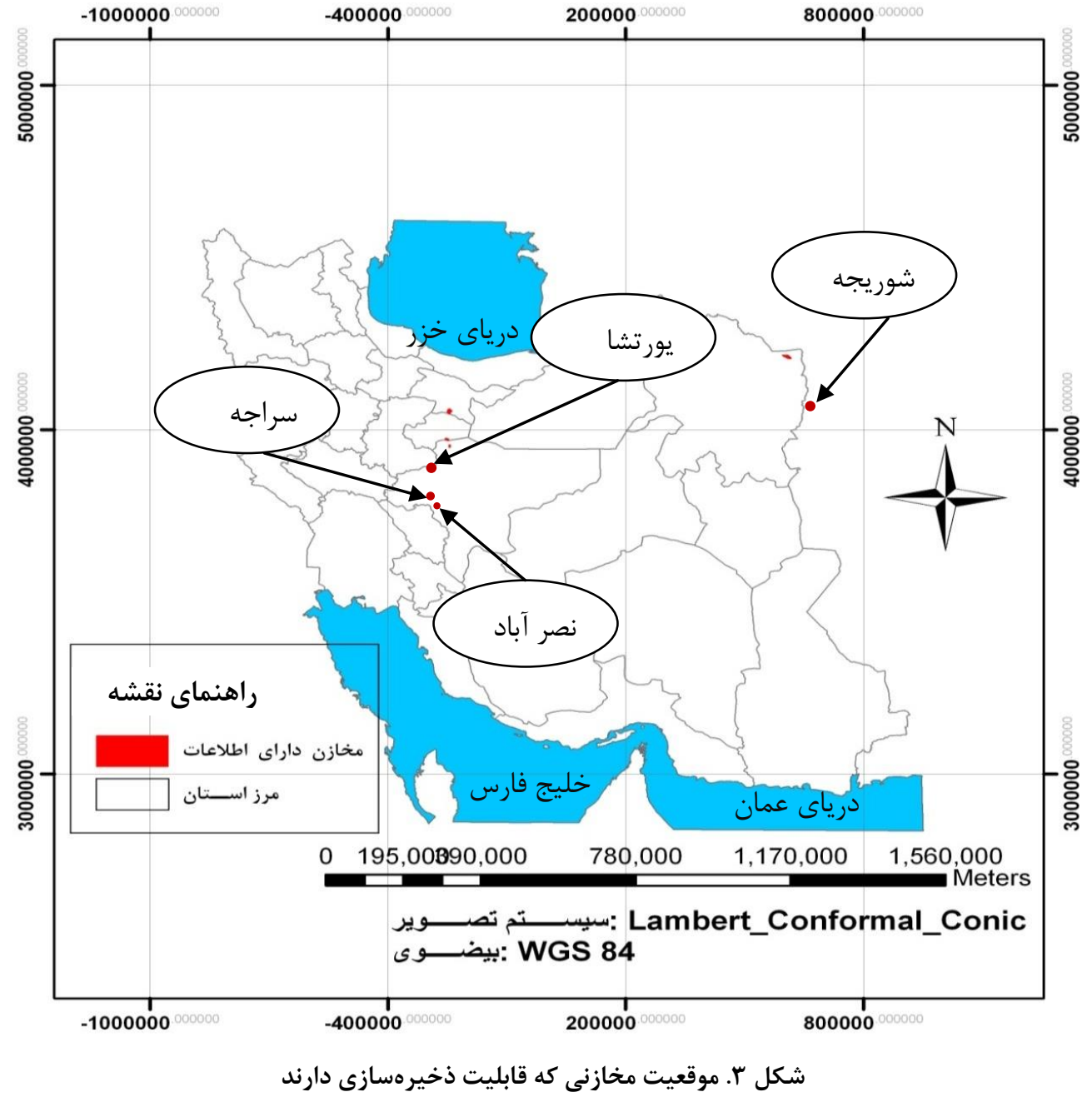


در ادامه، به توضيح و تشريح جدول ا برداخته مىشود: نوع مخزن: مخازن ذخيرهسازى زيرزمينى كاز، سـه نوعاند كه طبق نظر كارشناسـان از لحساظ هزينــه، مطالعات مورد نياز قبـل از انجـام ذخيـرهسـازى و ولهـ

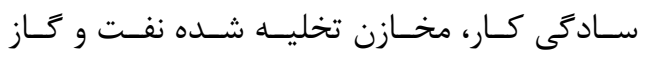

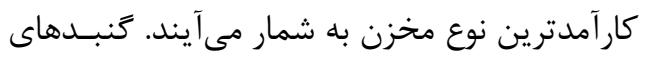

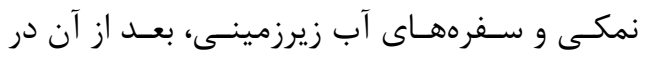
رتبههاى بعدى جاى مى گيرند. از آنجـا كـهـ معيـار

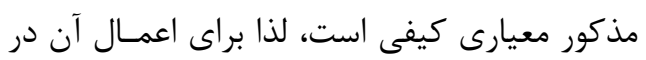

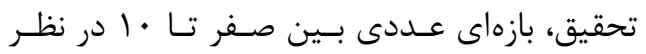
كرفته شد كه · ا نشاندهنده بهترين حالـت بـوده

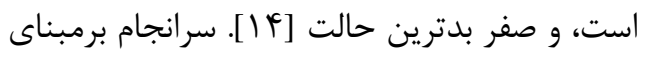
مطالعات صورت يذيرفته و طبق نظـر كارشناسـان

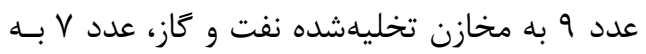

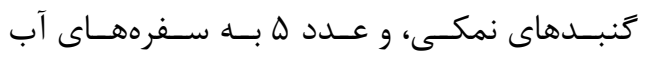
زيرزمينى اختصاص يافت.
البته بايد اشاره كرد كه مطالعات درباره گنبد نمكى نصرآباد همجنان ادامه دارد و در اين تحقيق از آخــرين اطلاعات موجود درباره اين مخزن استفاده شده است.

\section{r-r- - معيارهاى مورد استفاده و وزندهى به آنها}

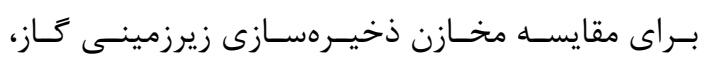
معيارهاى متفاوتى وجود دارند كه بـا توجـهـ بـهـ ميـزان اهميت معيارها و موجود يا در دسترس بودن دادههـاى

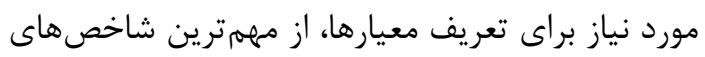

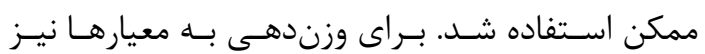

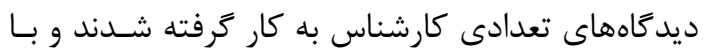

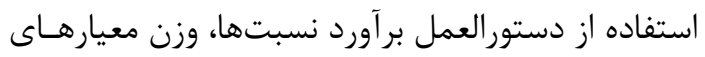

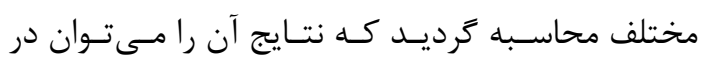
جدول ا مشاهده كرد. گفتنسى اسـت كـه جهـار معيـار مندرج در انتهاى جدول ا، معيارهـاى اضـافه شـده بـهـ

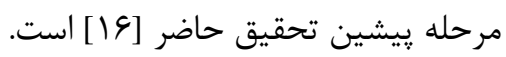

جدول 1. معيارهاى ارزيابى و وزن آنها

\begin{tabular}{|c|c|c|c|}
\hline وزن نهايى & ميانغين نمره تعلقيافته & \multicolumn{2}{|c|}{ 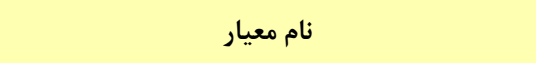 } \\
\hline $.1 \cdot 9$ & $r \cdot$ & \multicolumn{2}{|c|}{ نوع مخزن } \\
\hline$\cdot 1 \cdot 1 \mathrm{~F}$ & $1 / 10$ & \multicolumn{2}{|c|}{ ظرفيت مخزن } \\
\hline$\cdot / \cdot \Delta \varphi$ & $1 Y / \Delta$ & \multicolumn{2}{|c|}{ كاز يايه مورد نياز مخزن } \\
\hline$\cdot 1 \cdot \mathrm{VT}$ & 19 & \multicolumn{2}{|c|}{ قابليت تحويل مخزن } \\
\hline$\cdot 1 \cdot 9 V$ & 10 & \multicolumn{2}{|c|}{ قابليت تكرار سيكل برداشت/ تزريق } \\
\hline .1 .91 & $1 r / \Delta$ & صنعتى & \multirow{2}{*}{ فاصله از مراكز } \\
\hline$\cdot 1 \cdot v 9$ & IV & 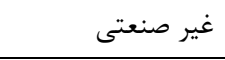 & \\
\hline$\cdot 1 \cdot 4 q$ & 11 & 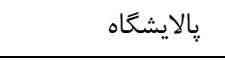 & \multirow{2}{*}{ فاصله از مراكز } \\
\hline .1 .91 & $1 \% / \Delta$ & خطوط لوله & \\
\hline$\cdot / \cdot \Delta T$ & $11 / 0$ & \multicolumn{2}{|c|}{ فاصله از شبكه راههاى اصلى } \\
\hline$\cdot 1 \cdot 90$ & $1 f / \Delta$ & \multicolumn{2}{|c|}{ دماى مناطق اطراف مخزن } \\
\hline$\cdot 1 \cdot 94$ & If & \multicolumn{2}{|c|}{ تراكم جمعيتى مناطق اطراف مخزن } \\
\hline$\cdot 1 \cdot+\boldsymbol{c}$ & $1 \cdot$ & \multicolumn{2}{|c|}{ عاز مورد استفاده مناطق } \\
\hline$\cdot 1 \cdot \mathrm{VV}$ & IV & \multicolumn{2}{|c|}{ آسيبرسانى مخزن به محيط زيست } \\
\hline$\cdot 1 \cdot 11$ & 11 & \multicolumn{2}{|c|}{ تعداد مراكز صنعتى مهمم تحت يوشش مخزن } \\
\hline
\end{tabular}


شامل 19 شهر يرمصرف و يرجمعيت كشـورند:

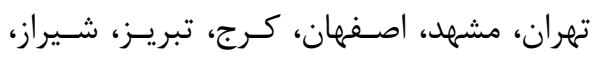

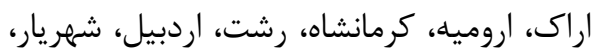

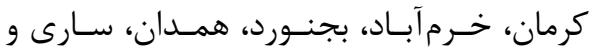

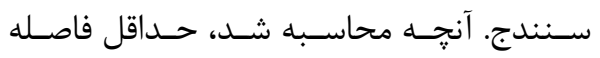
مخازن از اين شهرها بوده است. فاصله از مراكز توليد: براى محاسبه اين معيار، مراكز توليد به دو دسته تقسيم شدند: خطـوط لولـه كَاز سراسرى و يالايشكاهها.

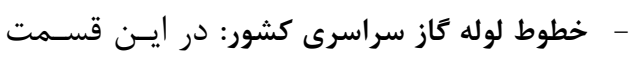

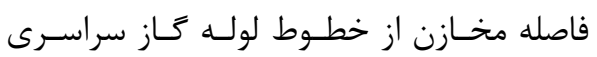

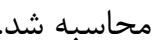

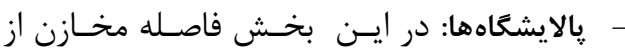
يالايشكاههاى كشور محاسبه شد. لذا بر مبنـاى

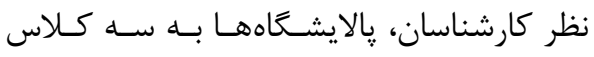

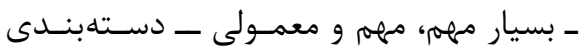

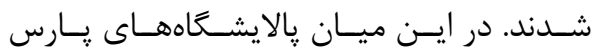

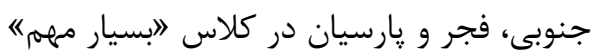
قرار گرفتند. اين پالايشكاهها توان توليد بسـيار بالايى دارند و مى توانند تمام كشـور را يوشـش تاري

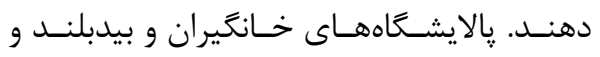

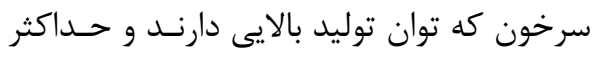

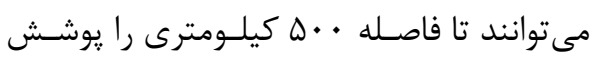
دهند، در كلاس "امهمه" جاى گرفتند. سـرانجام يالايشكاههاى ايلام و مسجد سليمان، كه تـوان

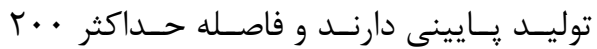
كيلـومترى را يوشـش مسى دهنــد، در كـلاس "امعمولى" قرار كرفتند. در نهايت براى اعمـال كردن اين معيار (با در نظر كرفتن قابليت توليد و محدوده تحت يوشش هر يك از يالايشكاهها) حداقل فاصله هر يك از مخازن با نزديكتــرين

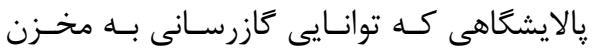
مورد نظر را داشته باشد، محاسبه شدند.
ظرفيت مخزن: ظرفيت مخزن به معناى كـل كــازى است كه مىتوان در آن ذخيره كرد. معمولاًا مخازن

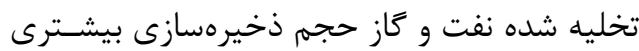

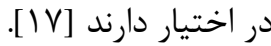

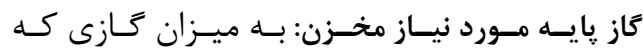

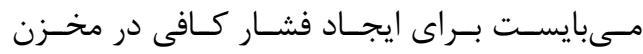
بلهنظور تضمين قابليت تحويل كازى كسه در دوره برداشت مى توان فروخت وجود داشـته باشـد، كـاز

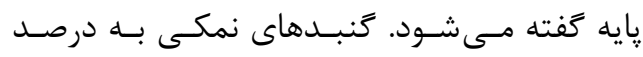

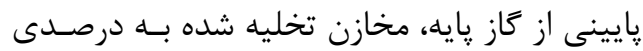

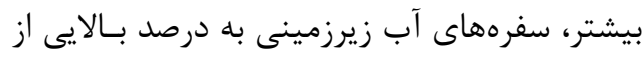

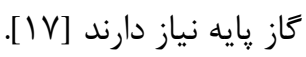

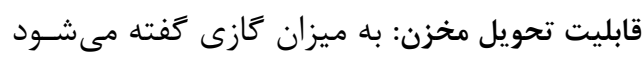
كه منبع ذخيرهسازى، توان توليد روزانهُ آن را براى

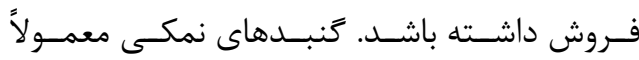

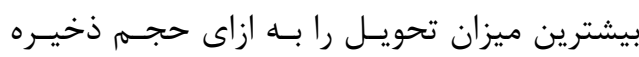

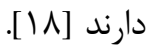
قابليت تكرار سيكل برداشت / تزريق: بـهـ امكــان يـاــا

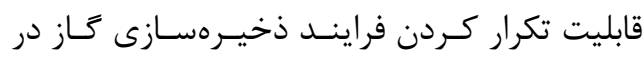

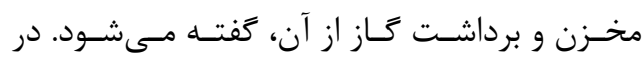
مخازن تخليه شده، معمولاً اين سيكل يــ بـ بـار در

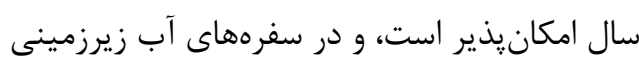

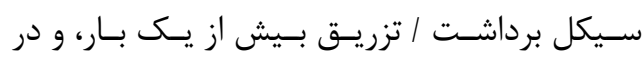
كنبدهاى نمكى تا بـيش از له بـار در سـال ممكـن

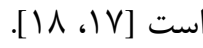
فاصله از مراكز ثقل مصرف: براى اعمـال ايـن معيـار، مراكز مصرف به دو دسته تقسيمبندى شدند: مراكز

$$
\text { صنعتى و مراكز غيرصنعتى. }
$$

- مراكز ثقل مصرف صنعتى: در اين قسمت فئنسي

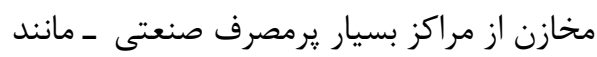
يتروشيمى ها، يالايشعاهها، نيرو كاههاى كَازى و و

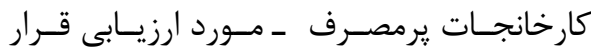
كرفت.

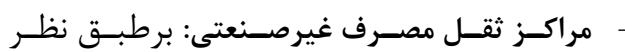

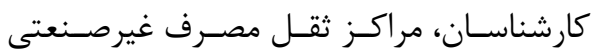


مخازن از نظر آسيبرسـانى بـه محسيط زيسـت بـاــا

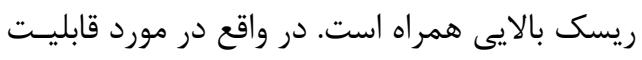

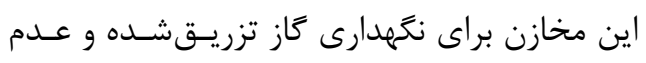

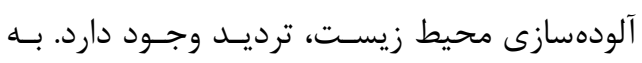

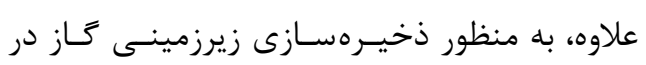

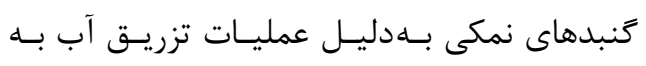

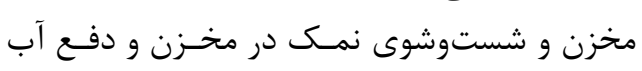

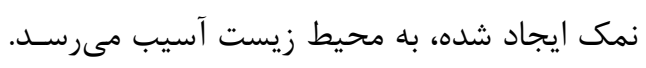

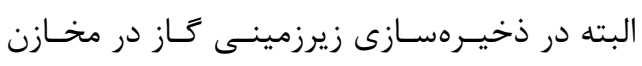
تخليه شده كاز و نفت، بهدليل اينكه ميـدان سـابقاً

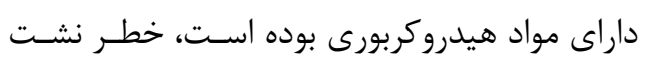

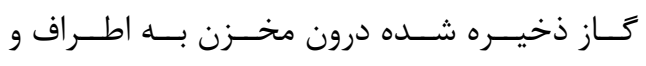

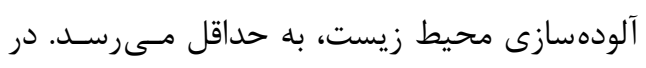

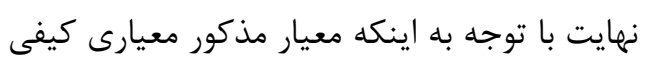

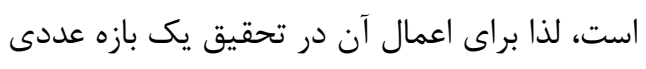

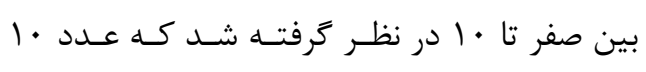

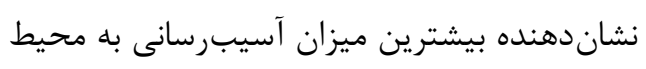

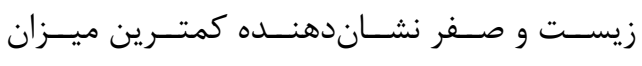

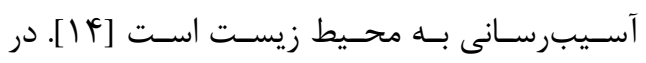

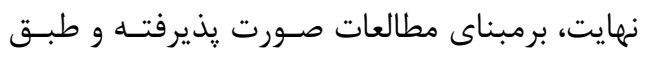

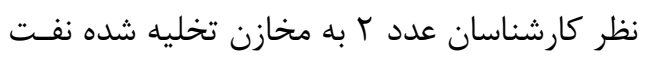

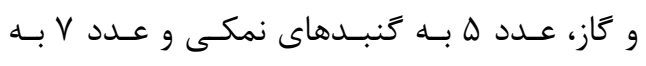
سفرههاى آب زيرزمينى اختصاص يافت.

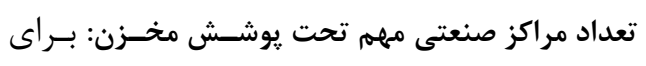

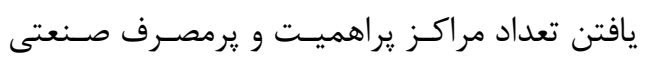
تحت يوشش هر مخزن، مطابق با نظر كارشناسـان

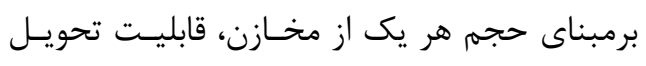

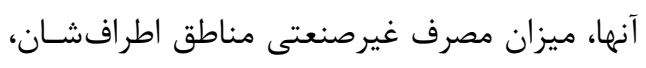

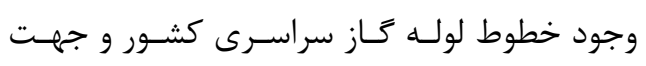

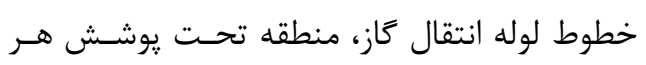

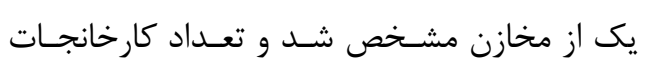

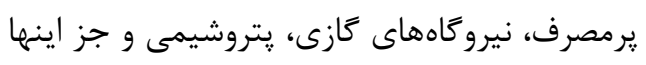
در منطقه مورد نظر محاسبه شد.

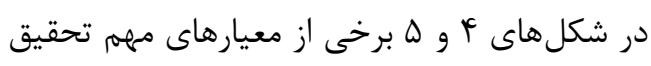
نمايش داده شدهاند.
فاصله از شبكه راههاى اصلى كشــور: در ايـن بخـش فاصله مخازن از شبكه راههاى اصلى كشور محاسبه كرديد. دماى مناطق اطراف مخازن: براى محاسبه اين معيار،

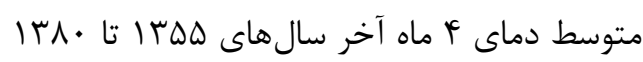

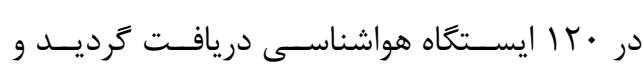

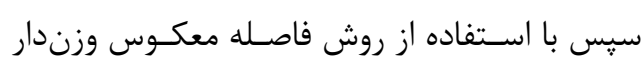
أز از كشور عددى بلهنوان دما تعلق يافت.

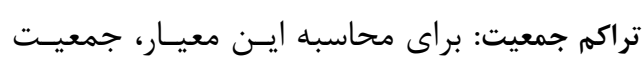

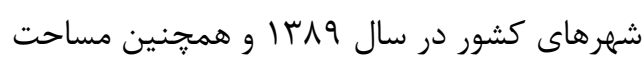

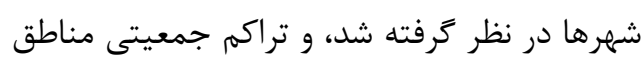

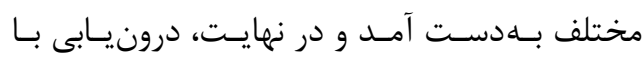

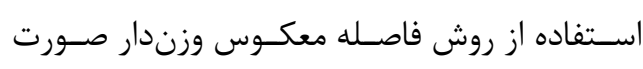

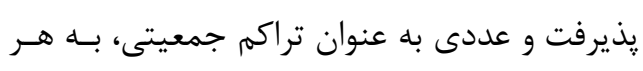
منطقه اختصاص يافت.

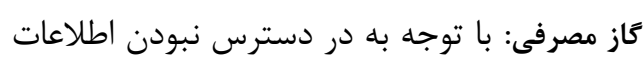

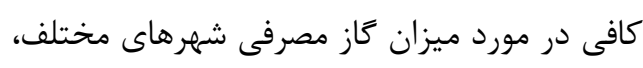

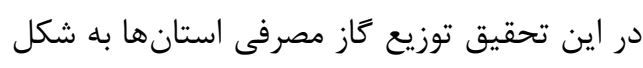

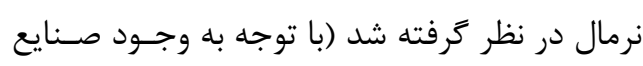

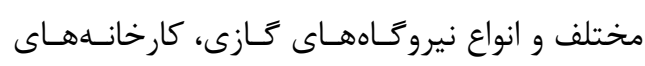

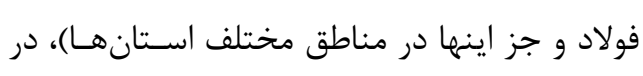

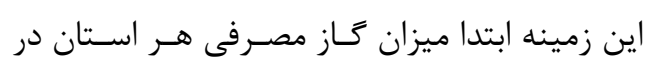

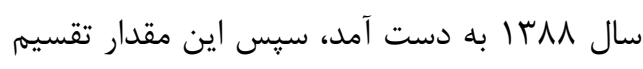

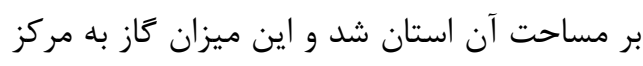

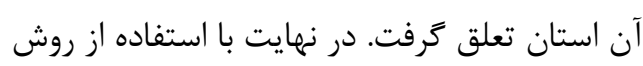

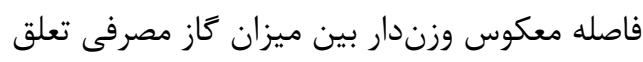
يافته به مراكز استانها، درونيابى انجام شد.

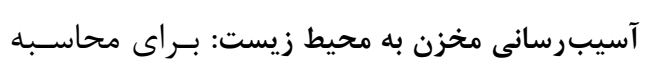

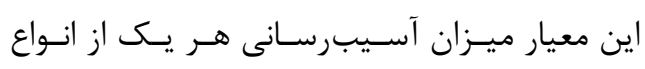

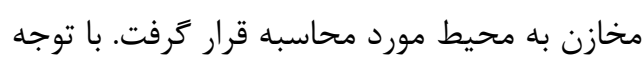

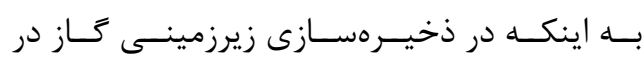

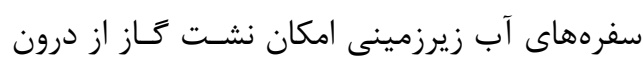

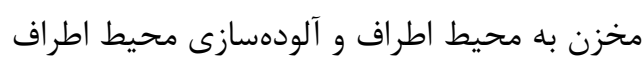

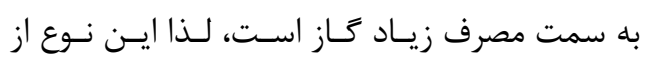




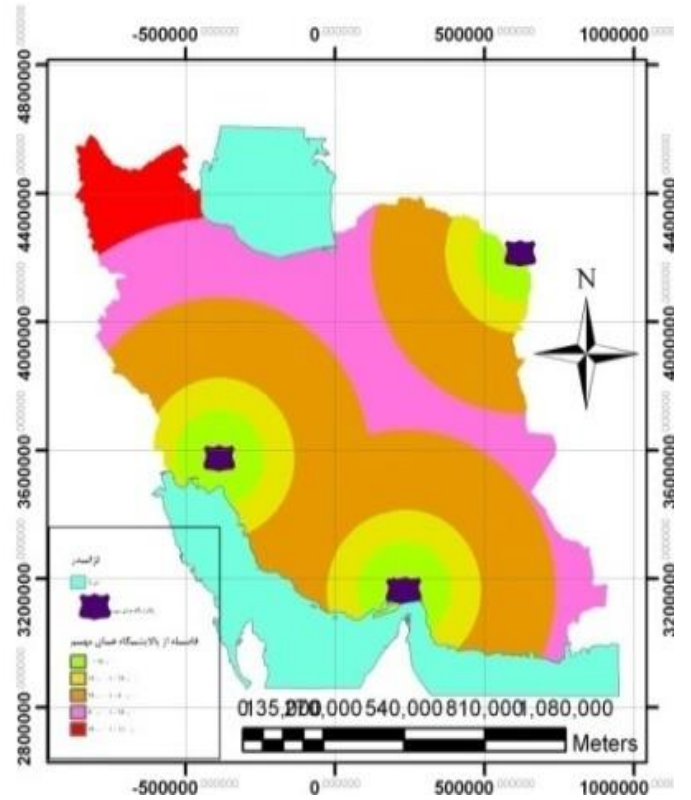

ب) فاصله از پالايشكاههاى مهم

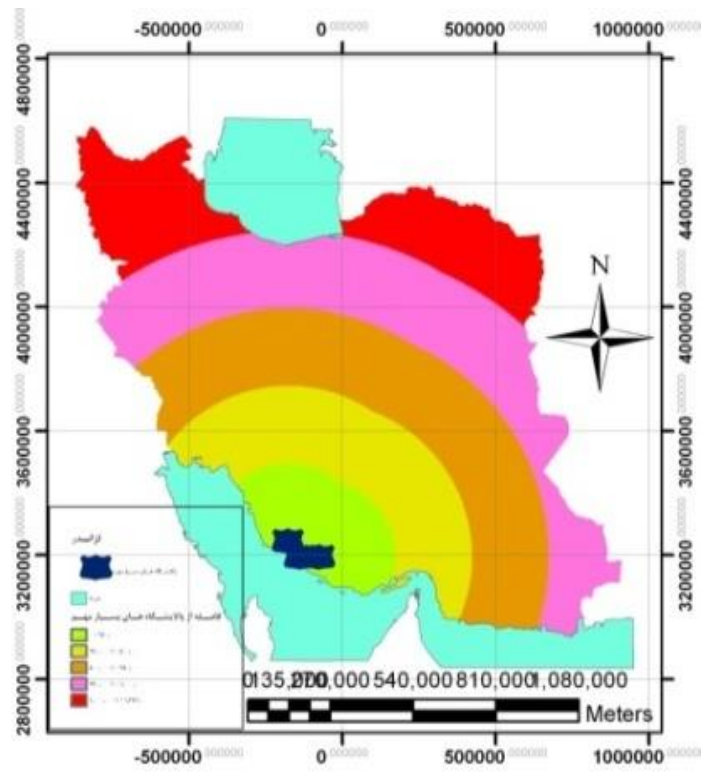

الف) فاصله از يالايشگاههاى بسيار مههم

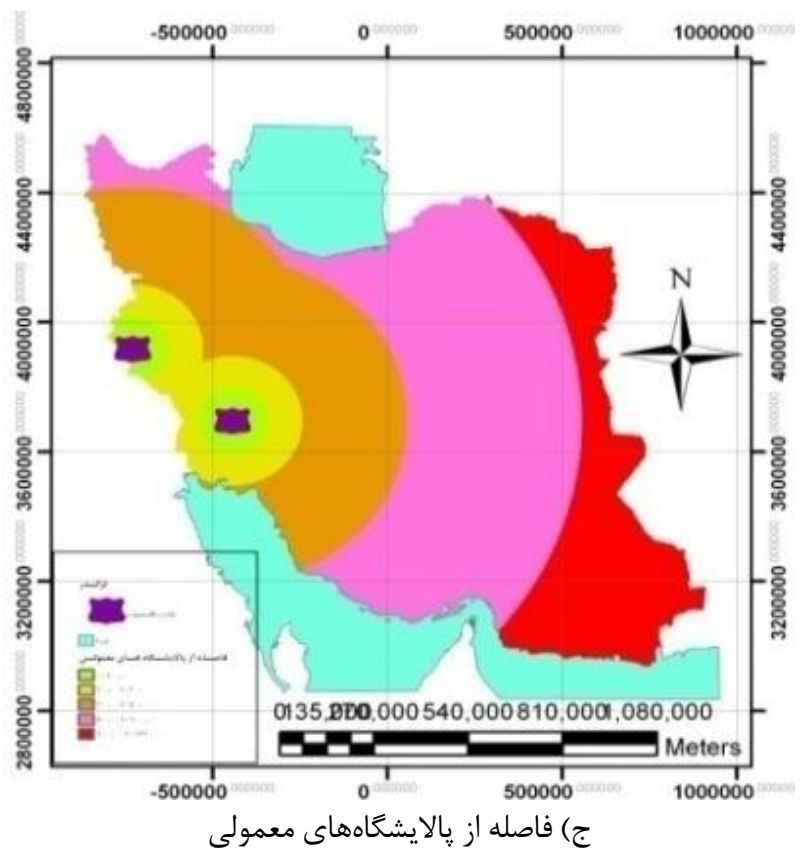

شكل F. فاصله از بالايشعاهها (متر) 


\section{اولويتبندى مخازن ذخيرهسازى زيرزمينى ...}

مهدى زنكنه و همكاران
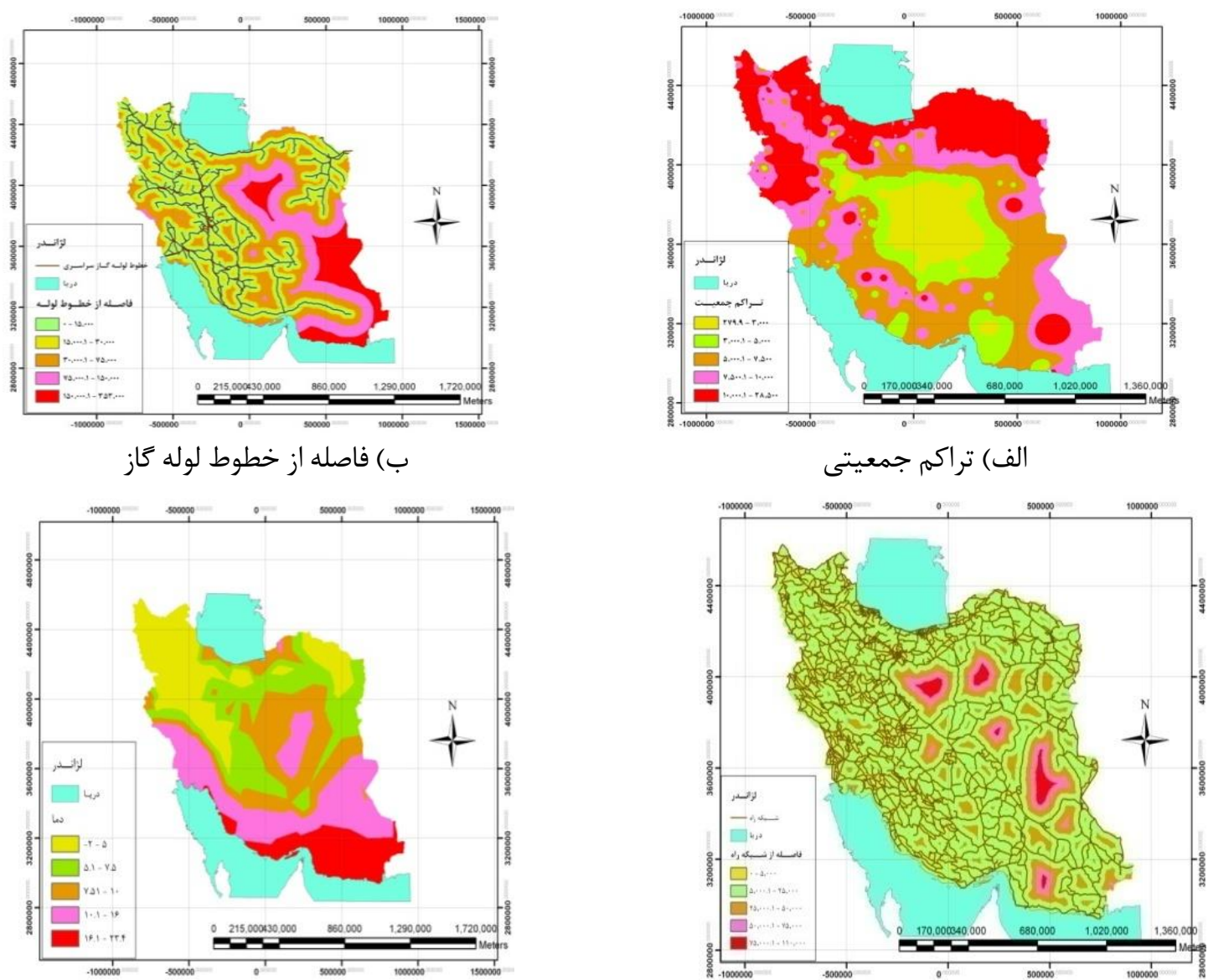

د) دما

ج) فاصله از شبكه ر اoاهـا
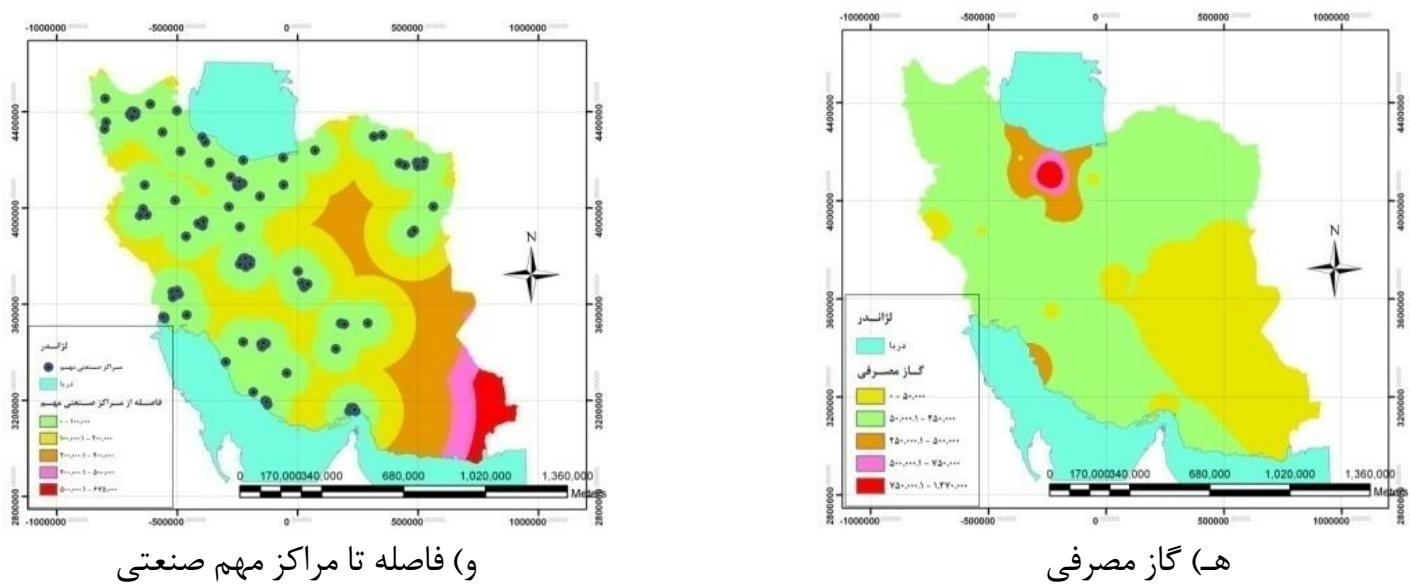

شكل ه. نقشه معيارهاى استفاده شده براى اولويتبندى مخازن در محيط GIS. الف- تراكم جمعيتى (نفر بر كيلومترمربع)،

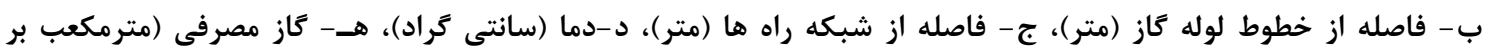
كيلومترمربع)، و ـ فاصله تا مراكز صنعتى مهـم (متر ). 
سِّ فاصله هر َزينه از راهحلهــاى آرمـانى مثبـت و

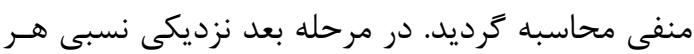

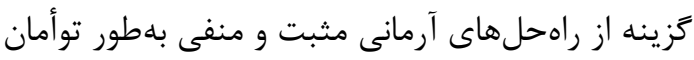

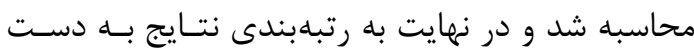

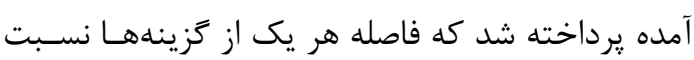

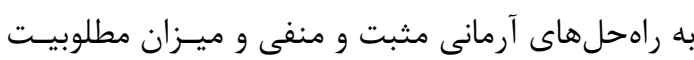

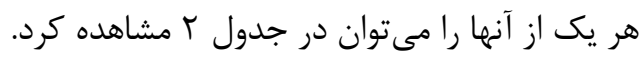

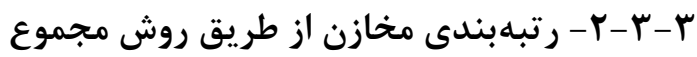
وزين و ردهبندى شده براى اعمال اين روش، ابتـدا مـاتريس تصـميم تشـكيل

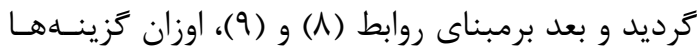
به ازاى شاخصهــا محاسـبه شـد، و سـيس بـا در نظــــ كرفتن بردار وزن معيارهـا و از طريـق رابطـهـ (V) بـردار ارجحيت از يايينترين سطح محاسبه كرديد كـه نتـايج آن در جدول ب ارائه شده است.

\section{F- ارزيابى نتايج تحقيق}

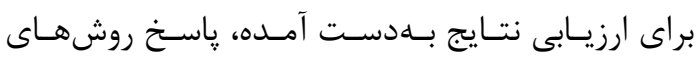

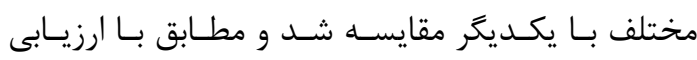

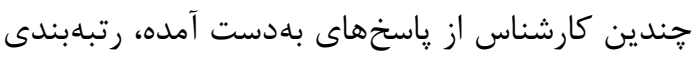

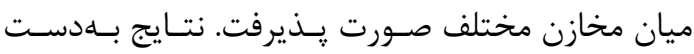

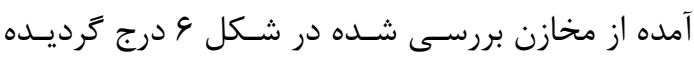

با توجه به شـكل و مشـخص مسىشـود كـه نتـايج رتبهبندى حاصل از فن رتبــبنـدى براسـاس تشـابه بـاــا حالت آرمانى، انطباق زيادى با رتبـهبنـدى كارشناسـان دارد؛ و اين امر به دليل استدلال منطقى موجود در اين روش است (در اين روش، فن رتبهبندى براساس تشـابه

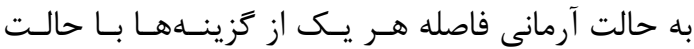
آرمـانى مثبـتـ و منفـى همزمــان مـورد ارزيـابى قـرار

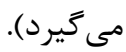

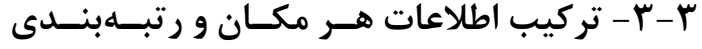
مكانها ابتدا مطابق با نظــــ كارشناسـان، معيارهـا بـهـ دو دســـه سود و هزينه تقسيمبندى شدند. معيارهـاى سـود (ايـن إنـان معيارها داراى مطلوبيت يكنواخت افزايشىاند، يعنى هر جه مقدار آنها افزايش يابد، شرايط كزينه متناظر بهبــود مىيابد) شاخصهاى نوع مخزن، حجم مخـزن، قابليـت تحويل مخزن، قابليت تكرار سـيكل برداشـت / تزريـق،

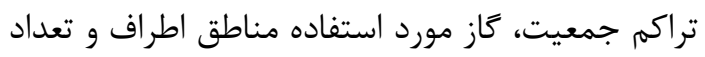
مراكز صنعتى مههم تحت يوشش مخزناند؛ و معيارهـاى

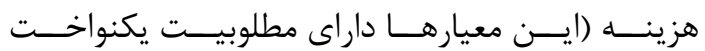
كاهشىاند، يعنى هر جه مقدار آنها افزايش يابد، شرايط كزينه متناظر بدتر مىشـود)؛ و شـاخصهــاى فاصـله از مراكز توليد، فاصله از شبكه راههاى اصلى كشور، ميزان

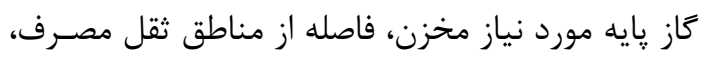

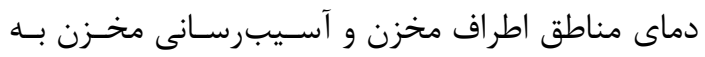

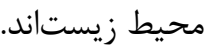

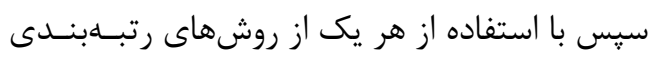

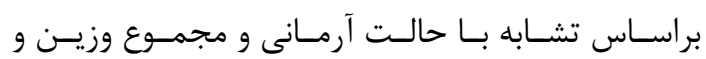

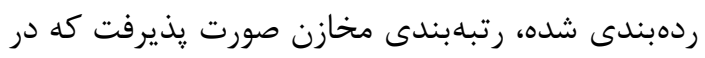

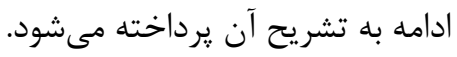

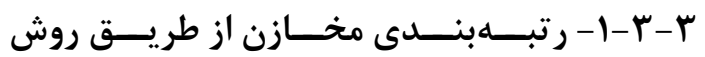
رتبدبندى براساس تشابه با حالت آرمانى

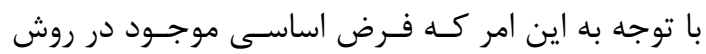

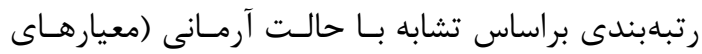
سود داراى مطلوبيت يكنواخت افزايشىاند، و معيارهـاى هزينه مطلوبيت يكنواخت كاهشى دارند) در اين تحقيق برقرار است، لذا بهمنظور رتبهبندى مخازن از طريق اين

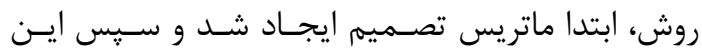
ماتريس نرمال كرديد و با استفاده از بردار وزن معيارهـا

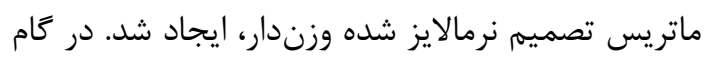

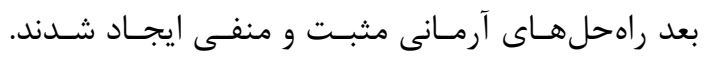




\section{اولويتبندى مخازن ذخيرهسازى زيرزمينى ...}

مهدى زنكنه و همكاران

جدول r. نتايج روش فن رتبهبندى براساس تشابه به حالت آرمانى

\begin{tabular}{|c|c|c|c|}
\hline فن رتبهبندى بر اساس تشابه به حالت آرمانى & فاصله از راهحل آرمانى منفى & فاصله از راهحل آرمانى مثبت & 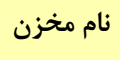 \\
\hline$\cdot 10 \cdot \cdot r$ & IVFTA & I/VrqV & 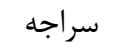 \\
\hline$\cdot 10 \cdot 1 \mathrm{~V}$ & I/ATVK & $|/ \wedge| \Delta \mid$ & 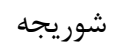 \\
\hline$\cdot \mid \Delta \cdot r \cdot$ & I/9rqV & I/GTEV & 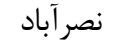 \\
\hline$\cdot / 4 q \cdot r$ & I/DGVV & 1/949. & 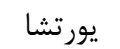 \\
\hline
\end{tabular}

جدول r. نتايج روش مجموع وزين و ردهبندى شده

\begin{tabular}{|c|c|}
\hline روش مجموع وزين و رده بندى شده & 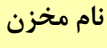 \\
\hline$\cdot / r T \Delta \Lambda$ & سراجه \\
\hline •/Tマ৭9. & 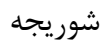 \\
\hline •/TTKI & نصر آباد \\
\hline$\cdot / T V I Q$ & 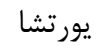 \\
\hline
\end{tabular}

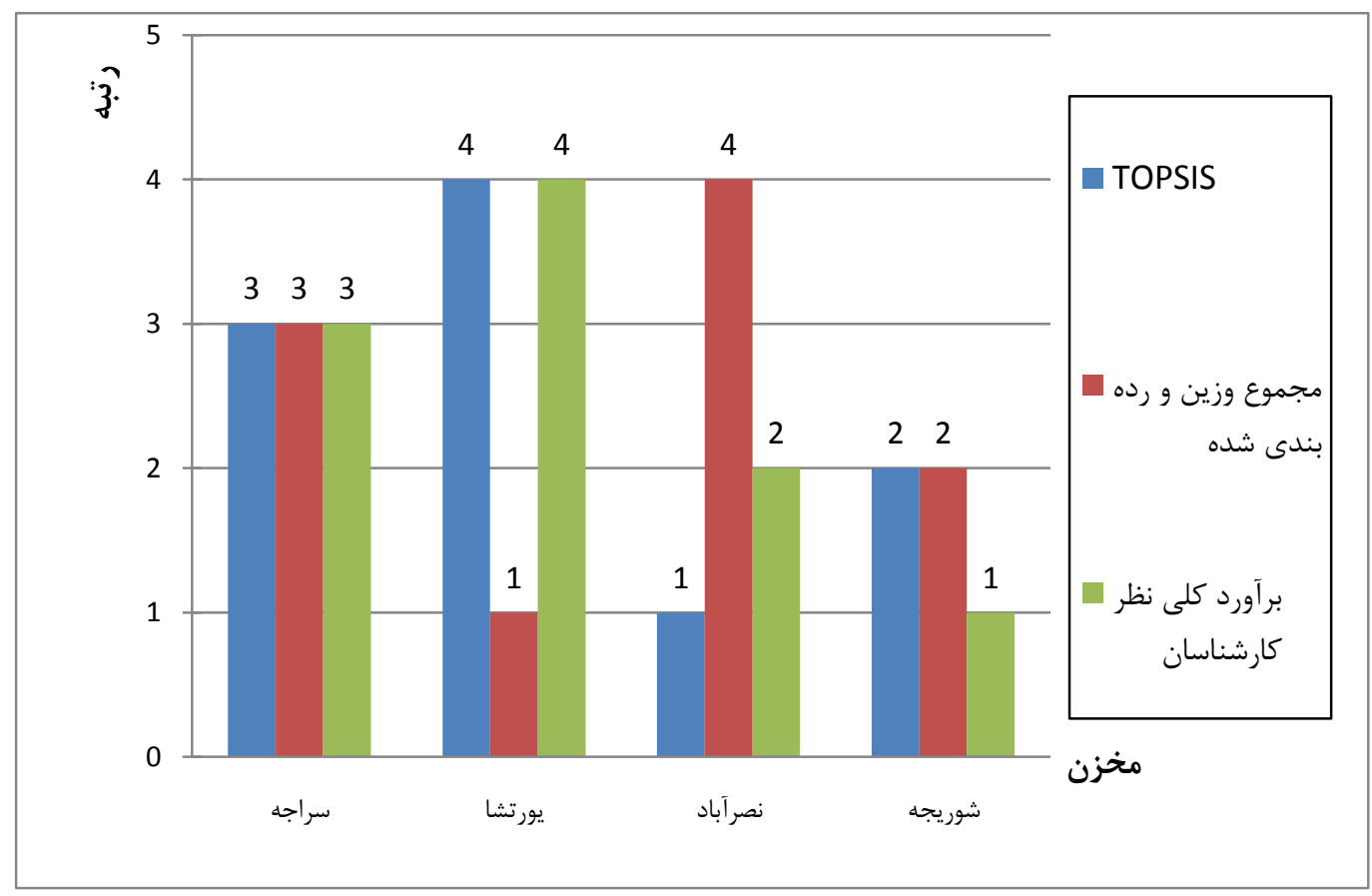

شكل \&. رتبههاى اختصاص يافته به مخازن 
مى آيد؛ و بعد از آن كنبد نمكى نصر آباد (در حوالى شهر كاشان) و مخازن سراجه (در حوالى شهر قمه) و يورتشـا

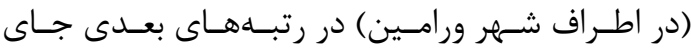

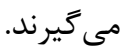

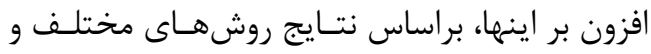

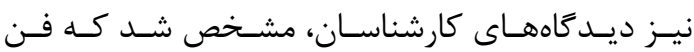

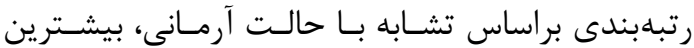
تشابه را با نظر كارشناسان دارد؛ و تنهـا تفـاوتى كـهـ در

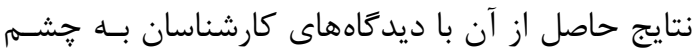
مى خورد، تفاوت در رتبهبندى مخزن شـوريجه و كَنبــد

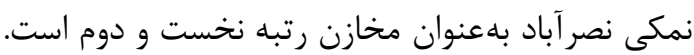
در واقع مى توان كفت كه اين روش براى محاسبه رتبـهـ

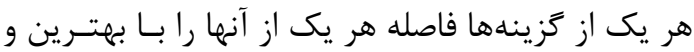

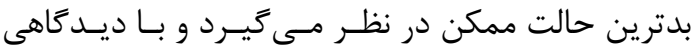
منطقى به رتبهبندى مخازن ذخيرهسازى زيرزمينى كاز

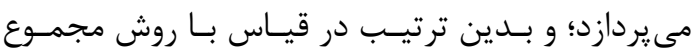
وزين و ردهبندى شده، كار آيى بالاتر و خطـاى كمتــى في

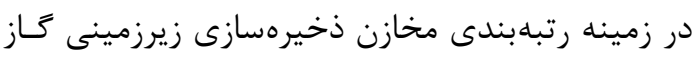

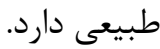

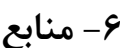

[1] Azin, R., 2009. Natural Gas Storage in Depleted Oil and Gas Underground Reservoirs. Journal of Chemical Engineering of Iran, 40, 45-52.

[2] USA: Federal Energy Regulatory Commission. 2004. Current State of and Issues Concerning Underground Natural Gas Storage. Docket No Ado4- 11- 000. pp. 1- 33.

[3] Malczewski, J., 1999. GIS and MultiCriteria Decision Analysis. New york: John Wiley \& Sons, 177- 194.

[4] Grataloupa, D. B., 2009. A Site Selection Methodology for $\mathrm{CO} 2$ Underground Storage in Deep. Science Direct, 10(2), 2930- 2936.

[5] Yami, B.A., 2009, Optimum Location of Wells using Multi-Criteria Analysis and Satellite Imagery. In: 4th National GIS symposium In Saudi Arabia, Dhahran.
همجرنين با توجه به برايند نتايج به دسـت آمـده از

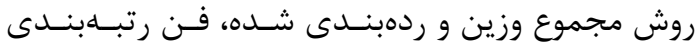

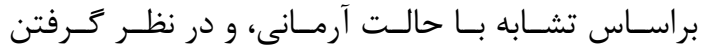
ديد كاههاى كارشناسان، مى توان بيان داشت كه مخـزن

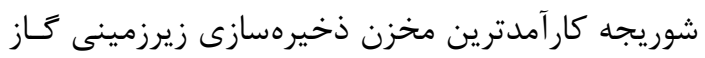

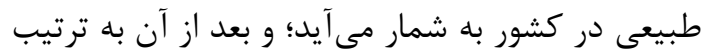

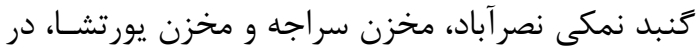
رتبههاى بعدى جاى مى گيرند. البتـهـ براسـاس نتـايج بــه دسـت آمــده از تحقيـق،

مى توان بيان داشت كه فن رتبهبندى براساس تشابه بـاــا

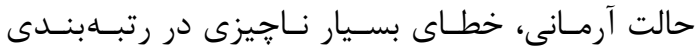
مخازن ذخيرهسازى زيرزمينى كاز دارد و در مقايسه بـا

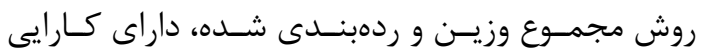
بيشتر و مطلوبترى است.

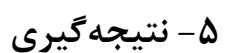

با افزايش مصرف كاز طبيعى در كشور و همجنين عـدم

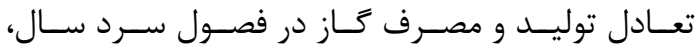

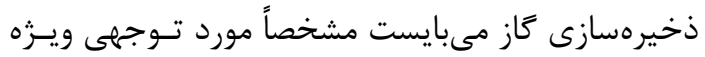

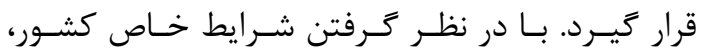

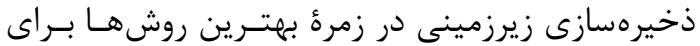

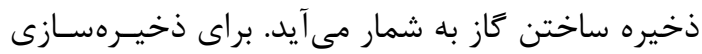
زيرزمينى كاز طبيعى، نخستين كام همانا يافتن مختزن مناسب براى اين كار است تا هزينه كازرسانى به مراكـز

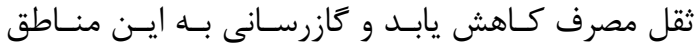
تسهيل و تسريع گردد.

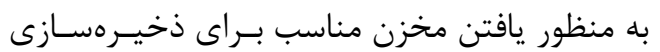
نيز مىبايست از روشهاى كاربردى و منطبق بر اصـول

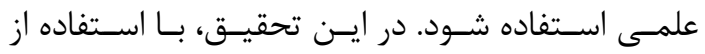

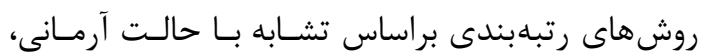

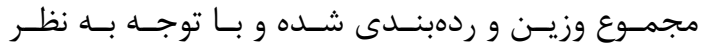

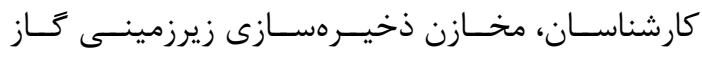

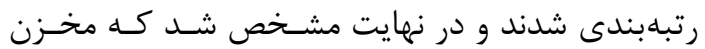
شوريجه (در اطراف شهر سرخس) بهترين مخزن بـراى ذخيرهسازى زيرزمينى كاز طبيعى در كشـور بـهـ شـمار 
[6] Company Sakhalin Energy, 2003. Liquefied Natural Gas Plant, Oil Export Terminal Site Selection Report.

[7] PB-KBB., 1998. Advanced Under Ground Gas Storage Concepts. PB-KBB Energy Company Report.

[8] Samadi, R. and Eghbali, S., 2008. Site Selection for the Construction of Thermal Power Plants to Help GIS and AHP. In: The First Conference of GIS Applications in Planning, Designing and Monitoring Iimproved Management and Operation of Electricity Networks. Regional Electric Company, Mazandaran and Golestan.

[9] Nassiri, A., 2009. Application of Multi Criteria Decision Making Techniques Integrated with GIS in Urban Land Use. In: Geomatics 88 Conference. NCC, Tehran, Iran, April 2010. pp. 1-8.

[10]Basiri, M. and Shakur Shahabi, R., 2007. Ranking Countries by Way of Minerals Similar to the Ideal Decision. Mining Journal Research. 2(4), 1-10.

[11] Sabeti Saleh, E., 2009. Multi Criteria Decision Model for Ranking Fuzzy Applicant Bank Financing. In: The Second International Conference on Development of supply of Financing System in Iran, Tehran, Iran.

[12] Opricovic, S., Tzeng, G., 2002. Compromise Solution by MCDM Methods: A Comparative Analysis of VIKOR and TOPSIS. European Journal of Operational Research, 156, 444- 454.
[13] Shih, H.S., 2008. Incremental Analysis for MCDM with an Application to Group TOPSIS. European Journal of Operational Research, 186, 720-734.

[14] Asgharpour, M.J., 2009. Multi Criteria Decision Making. Iran: University of Tehran, press.

[15] Kiavarz Moghaddam, H., 2005. Optimal Routing of Oil and Gas Pipelines to Assist Geospatial Information Systems. M.Sc. Thesis, College of Engineering. University of Tehran.

[16]Zangeneh, M., Delavar, M.R. Moshiri, B. and Ghavampour, S., 2011. Rating Underground Storage Tanks of Natural Gas Based on Multi Criteria Decision Making Integrated Spatial and Geospatial Information Systems. In: GIS \& SDI 89 Conference. NCC, Tehran, Iran, 1-14.

[17]Dietert, J.A. and D.A. Pursell, 2000. Underground Natural Gas Storage. Simmons \& Company International, 1-14.

[18] http://www.eia.doe.gov/pub/oil_gas/natural_ gas/analysis_publications/storagebasics/stor agebasics.htm 1 . 



\title{
Prioritizing Underground Storage Tanks of Natural Gas Using GIS and TOPSIS
}

\author{
Zangeneh M. ${ }^{* 1}$, Delavar M.R. ${ }^{2}$, Moshiri B. ${ }^{3}$, Ghavampour S ${ }^{4}$, Effati M. ${ }^{5}$ \\ 1- M.Sc. Student GIS Division, Dep. of Surveying and Geomatic Eng., College of Eng., University of Tehran \\ 2- Associate Prof. Center of Excellence in Geomatic Eng. and Disaster Management, Dep. of Surveying and Geomatic Eng., University of Tehran \\ 3- Prof. in Control \& Intelligent Processing, Center of Excellence, School of Electrical and Computer Eng., University of Tehran \\ 4- Assistant Prof., Dep. of Industry Eng., Ghazvin University of Work \\ 5- Ph.D. Candidate GIS Division, Dep. of Surveying and Geomatic Eng., College of Eng., University of Tehran
}

\begin{abstract}
In this study, an efficient approach is suggested to prioritize the natural gas storage in existing underground reservoirs. The paper uses expert knowledge and integrates the Geospatial Information System (GIS) with spatial multi criteria decision making. The proposed method is based on TOPSIS as well as Hierarchical Additive Weighting Method. In order to consider different options, the most important possible criteria have been considered in this study, including: reservoir characteristics, distance from the center of gravity taking, distance from production centers, distance from the country's road network, the temperature around the reservoir areas, environmental characteristics of the reservoir, consumption gas in areas around the reservoir, population density, and the number of important industrial centers covered by each of the reservoirs. To evaluate the results of research, results of implemented methods were compared with each others and according to evaluation obtained from several experts; the final prioritization of different reservoirs due to their performances has been done. The results indicate that TOPSIS is more precise than Hierarchical Additive Weighting Method, and conform to experts opinions about prioritization of natural gas storage in underground reservoirs.
\end{abstract}

Keywords: Geospatial Information Systems, Spatial Multi Criteria Decision Making, Underground Storage of Natural Gas, Hierarchical Additive Weighting Method, TOPSIS.

* Correspondence Address: Geospatial Information System Group, Dep. of Geomatics, College of Engineering, University of Tehran. Tel: 09123388941. Email: m. zangeneh@ut.ac.ir 